\title{
Cobalt: An Essential Micronutrient for Plant Growth?
}

\author{
Xiu Hu ${ }^{1}$, Xiangying Wei ${ }^{2 *}$, Jie Ling $^{3}$ and Jianjun Chen ${ }^{4 *}$ \\ ${ }^{1}$ College of Horticulture and Landscape Architecture, Zhongkai University of Agriculture and Engineering, Guangzhou, China, \\ ${ }^{2}$ Institute of Oceanography, Minjiang University, Fuzhou, China, ${ }^{3} \mathrm{He}$ Xiangning College of Art and Design, Zhongkai \\ University of Agriculture and Engineering, Guangzhou, China, ${ }^{4}$ Department of Environmental Horticulture and Mid-Florida \\ Research and Education Center, Institute of Food and Agricultural Sciences, University of Florida, Apopka, FL, United States
}

\section{OPEN ACCESS}

Edited by:

Antonios Chrysargyris, Cyprus University of

Technology, Cyprus

Reviewed by:

Timothy O. Jobe,

University of Cologne, Germany

Guilan Duan,

Research Center for

Eco-Environmental Sciences

(CAS), China

${ }^{*}$ Correspondence:

Jianjun Chen

jjchen@ufl.edu

Xiangying We

xiangyingwei@mju.edu.cn

Specialty section:

This article was submitted to

Crop and Product Physiology,

a section of the journal

Frontiers in Plant Science

Received: 31 August 2021 Accepted: 29 September 2021

Published: 16 November 2021

Citation:

Hu X, Wei X, Ling J and Chen J (2021) Cobalt: An Essential Micronutrient for

Plant Growth?

Front. Plant Sci. 12:768523. doi: 10.3389/fpls.2021.768523
Cobalt is a transition metal located in the fourth row of the periodic table and is a neighbor of iron and nickel. It has been considered an essential element for prokaryotes, human beings, and other mammals, but its essentiality for plants remains obscure. In this article, we proposed that cobalt $(\mathrm{Co})$ is a potentially essential micronutrient of plants. Co is essential for the growth of many lower plants, such as marine algal species including diatoms, chrysophytes, and dinoflagellates, as well as for higher plants in the family Fabaceae or Leguminosae. The essentiality to leguminous plants is attributed to its role in nitrogen $(\mathrm{N})$ fixation by symbiotic microbes, primarily rhizobia. Co is an integral component of cobalamin or vitamin $B_{12}$, which is required by several enzymes involved in $\mathrm{N}_{2}$ fixation. In addition to symbiosis, a group of $\mathrm{N}_{2}$ fixing bacteria known as diazotrophs is able to situate in plant tissue as endophytes or closely associated with roots of plants including economically important crops, such as barley, corn, rice, sugarcane, and wheat. Their action in $\mathrm{N}_{2}$ fixation provides crops with the macronutrient of $\mathrm{N}$. Co is a component of several enzymes and proteins, participating in plant metabolism. Plants may exhibit Co deficiency if there is a severe limitation in Co supply. Conversely, Co is toxic to plants at higher concentrations. High levels of Co result in pale-colored leaves, discolored veins, and the loss of leaves and can also cause iron deficiency in plants. It is anticipated that with the advance of omics, Co as a constitute of enzymes and proteins and its specific role in plant metabolism will be exclusively revealed. The confirmation of Co as an essential micronutrient will enrich our understanding of plant mineral nutrition and improve our practice in crop production.

Keywords: cobalamin, cobalt, endophytes, essential nutrients, micronutrients, symbiosis, vitamin $B_{12}$, transporter

\section{INTRODUCTION}

Cobalt is an essential nutrient for prokaryotes, human beings, and other mammals but has not been considered an essential micronutrient for plants. Instead, this element, along with other elements, such as aluminum ( $\mathrm{Al}$ ), selenium $(\mathrm{Se})$, silicon $(\mathrm{Si})$, sodium $(\mathrm{Na})$, and titanium $(\mathrm{Ti})$, has been considered as a beneficial element for plant growth (Pilon-Smits et al., 2009; Lyu et al., 2017). An element that can improve plant health status at low concentrations but has toxic effects at high concentrations is known as a beneficial element (Pais, 1992). For an element to be considered essential, it must be required by plants to complete its life cycle, must not be replaceable by other 
elements, and must directly participate in plant metabolism (Arnon and Stout, 1939). It has been well-documented that there are 92 naturally occurring elements on the earth, wherein 82 of which have been found in plants (Reimann et al., 2001). Plants are able to absorb elements from soils either actively or passively due to their sessile nature. The occurrence of an element in plants, particularly in shoots, must have a purpose. Active transport of an element from roots to shoots may indicate a certain role it plays in plants. As stated in the study by Bertrand (1912), potentially, every element has a biological function that can be assessed properly against a background of a deficiency state, and every element is toxic when present at high enough concentrations, which is known as Bertrand's rule of metal necessity.

Significant progress has been made in plant mineral nutrition since the publication of Bertrand's rule (Bertrand, 1912) and the essentiality concept (Arnon and Stout, 1939). Among the beneficial elements, cobalt (Co) could potentially be an essential plant micronutrient. Co is a core element of cobalamin (vitamin $\mathrm{B}_{12}$ and its derivatives) and a cofactor of a wider range of enzymes and a component of different proteins in prokaryotes and animals (Maret and Vallee, 1993; Kobayashi and Shimizu, 1999; Harrop and Mascharak, 2013; Odaka and Kobayashi, 2013). Co-containing enzymes and proteins in plants require further investigation and clarification. Rhizobia and other nitrogen (N)-fixation bacteria require $\mathrm{Co}$ and cobalamin for fixing atmosphere dinitrogen $\left(\mathrm{N}_{2}\right)$ into ammonia $\left(\mathrm{NH}_{3}\right)$, providing plants with the essential macronutrient of $\mathrm{N}$. Co plays a vital role in interaction with iron $(\mathrm{Fe})$, nickel $(\mathrm{Ni})$, and zinc $(\mathrm{Zn})$ in maintaining cellular homeostasis. Similar to other essential micronutrients, plants respond to Co concentrations in soil: at low concentrations, it promotes plant growth but causes phytotoxicity at higher concentrations. However, it is different from other beneficial elements, as plants do exhibit Co deficiency when grown in soils with limited supply.

The objective of this article was to concisely review the importance of $\mathrm{Co}$ as a plant micronutrient including its role in $\mathrm{N}$ fixation, the occurrence of coenzyme or proteins, and its effects on plant growth as well as Co deficiency and toxicity. We intended that this review could raise an awareness that Co is a potentially essential micronutrient of plants, and further research is needed to confirm this proposition.

\section{COBALT AND NITROGEN-FIXATION IN PLANTS}

Cobalt was isolated by Brandt in 1735 and recognized as a new element by Bergman in 1780 (Lindsay and Kerr, 2011). The importance of Co to living things was realized in the 1930s during the investigation of ruminant livestock nutrition in Australia (Underwood and Filmer, 1935). Co was discovered to be essential for animals as it is a component of cobalamin. Five scientists were awarded Nobel Prizes for the investigation of cobalamin (Carpenter, 2004).

\section{Cobalt Is a Core Element of Cobalamin}

Cobalamin is a large molecule $\left(\mathrm{C}_{63} \mathrm{H}_{88} \mathrm{O}_{14} \mathrm{~N}_{14} \mathrm{PCo}\right)$ comprised of a modified tetrapyrrole ring known as corrin with $\mathrm{Co}^{3+}$ in the center (Osman et al., 2021). Co is not inter-exchangeable with other metals in the cobalamin and cannot be released from the ring unless the ring is broken (Yamada, 2013), implying the significance of Co to cobalamin. There are two biologically active forms of cobalamin, namely, methylcobalamin and adenosylcobalamin in ruminants (Gonzalez-Montana et al., 2020). In human beings, Co is a cofactor of two enzymes, namely, ethylmalonyl-CoA mutase (MCM) and methionine synthase. MCM catalyzes the reversible isomerisation of 1methylmalonyl-CoA to succinyl-CoA. A deficiency of MCM causes an inherited metabolism disorder commonly known as methylmalonic aciduria. Methionine synthase utilizes cobalamin as a cofactor to produce methionine from homocysteine (Table 1). Reduced activity of this enzyme leads to megaloblastic anemia (Tjong et al., 2020). Ruminant animals produce vitamin $\mathrm{B}_{12}$ if there is an appropriate supply of Co in their diet. It was reported that 3 to $13 \%$ of the Co was incorporated into cobalamin by bacteria in the ruminant animals (Huwait et al., 2015).

\section{Cobalamin Biosynthesis in Bacteria and Archaea}

The natural forms of vitamin $\mathrm{B}_{12}$ are 1,5deoxyadenosylcobalamin, hydroxycobalamin, and methylcobalamin (Nohwar et al., 2020). They are synthesized by a selected subset of bacteria and archaea (Heal et al., 2017; Guo and Chen, 2018), which include Bacillus, Escherichia, Fervidobacterium, Kosmotoga, Lactobacillus, Mesotoga, Nitrosopumilus, Petrotoga, Propionibacterium, Proteobacteria, Pseudomonas, Rhodobacter, Rhizobium, Salmonella, Sinorhizobium, Thermosipho, and Thermotoga (Doxey et al., 2015; Fang et al., 2017). Cyanocobalamin is not a natural form but commercially synthesized $B_{12}$. The production of vitamin $\mathrm{B}_{12}$ by these microbes involves about 30 enzymatic steps through either aerobic or anaerobic pathways. In addition to being essential for fat and carbohydrate metabolism and synthesis of DNA, vitamin $B_{12}$ is a cofactor of many enzymes. There are more than 20 cobalamin-dependent enzymes in those prokaryotes including diol dehydratase, ethanolamine ammonialyase, glutamate, and methylmalonyl-CoA mutase, methionine synthase, and ribonucleotide reductase (Marsh, 1999) (Table 1). These enzymes catalyze a series of transmethylation and rearrangement reactions (Rodionov et al., 2003). Thus, Co is essential for those archaea and bacteria.

\section{Cobalt Plays an Important Role in Biological Nitrogen Fixation}

Biological $\mathrm{N}$ fixation is a process of converting $\mathrm{N}_{2}$ from the atmosphere into plant-usable form, primarily $\mathrm{NH}_{3}$. Biological $\mathrm{N}$ fixation (BNF) is carried out by a group of prokaryotes known as diazotrophs, which are listed in Table 2, including bacteria, mainly Rhizobium, Frankia, Azotobacter, Mycobaterium, Azospirillum, and Bacillus; Archaea, such as Methanococcales, Methanobacteriatles, 
TABLE 1 | Cobalt-containing enzymes, proteins, and transporter relevant or potentially relevant to plant metabolisms.

\begin{tabular}{|c|c|c|c|c|}
\hline Type & Name & Role & Organism & References \\
\hline \multirow[t]{6}{*}{$\begin{array}{l}\text { Corrin Co } \\
\text { enzymes }\end{array}$} & $\begin{array}{l}\text { Ethylmalonyl-CoA mutase } \\
\text { (MCM) }\end{array}$ & $\begin{array}{l}\text { Catalysis of reversible isomerisation of } \\
\text { I-methylmalonyl-CoA to succinyl-CoA }\end{array}$ & Mammals and bacteria & $\begin{array}{l}\text { Odaka and Kobayashi, } \\
\text { 2013; Gonzalez-Montana } \\
\text { et al., } 2020\end{array}$ \\
\hline & Methionine synthase & Synthesis of methionine from homocysteine & Mammals and bacteria & $\begin{array}{l}\text { Odaka and Kobayashi, } \\
\text { 2013; Gonzalez-Montana } \\
\text { et al., } 2020\end{array}$ \\
\hline & $\begin{array}{l}\text { Methylcobalamin- } \\
\text { dependent } \\
\text { methyltransferase }\end{array}$ & $\begin{array}{l}\text { Transfer of a methyl group from different methyl } \\
\text { donors to acceptor molecules }\end{array}$ & Mammals & $\begin{array}{l}\text { Bridwell-Rabb and Drennan, } \\
2017\end{array}$ \\
\hline & $\begin{array}{l}\text { Adenosylcobalamin- } \\
\text { dependent } \\
\text { isomerases }\end{array}$ & $\begin{array}{l}\text { Catalysis of a variety of chemically difficult } \\
\text { 1,2-rearrangements that proceed through a } \\
\text { mechanism involving free radical intermediates }\end{array}$ & Mammals and bacteria & Marsh and Drennan, 2001 \\
\hline & $\begin{array}{l}\text { Ethanolamine } \\
\text { ammonia-lyase }\end{array}$ & $\begin{array}{l}\text { Conversion of ethanolamine to acetaldehyde } \\
\text { and ammonia }\end{array}$ & $\begin{array}{l}\text { Listeria monocytogenes and } \\
\text { Escherichia coli }\end{array}$ & $\begin{array}{l}\text { Harrop and Mascharak, } \\
2013\end{array}$ \\
\hline & Ribonucleotide reductase & $\begin{array}{l}\text { Catalysis of the production of } \\
\text { deoxyribonucleotides needed for DNA } \\
\text { synthesis }\end{array}$ & Bacteria, mammals, yeast, and plants & $\begin{array}{l}\text { Elledge et al., 1992; Yoo } \\
\text { et al., } 2009\end{array}$ \\
\hline \multirow[t]{11}{*}{$\begin{array}{l}\text { Non-corrin Co } \\
\text { enzymes }\end{array}$} & Nitrile hydratase (NHase) & $\begin{array}{l}\text { Hydration of aromatic and small aliphatic nitriles } \\
\text { into the corresponding amides }\end{array}$ & $\begin{array}{l}\text { Rhodococcus rhodochrous and } \\
\text { Pseudonocardia thermophila }\end{array}$ & $\begin{array}{l}\text { Harrop and Mascharak, } \\
\text { 2013; Odaka and } \\
\text { Kobayashi, } 2013\end{array}$ \\
\hline & $\begin{array}{l}\text { Thiocyanate hydrolase } \\
\text { (THase) }\end{array}$ & $\begin{array}{l}\text { Hydration and subsequent Hydration of } \\
\text { thiocyanate to produce carbonyl sulfide and } \\
\text { ammonia }\end{array}$ & $\begin{array}{l}\text { Thiobacillus thioparus (a } \\
\text { Gram-negative betaproteobacterium) }\end{array}$ & $\begin{array}{l}\text { Harrop and Mascharak, } \\
2013\end{array}$ \\
\hline & $\begin{array}{l}\text { Methionine aminopeptidase } \\
\text { (MA) }\end{array}$ & $\begin{array}{l}\text { Cleavage of the } \mathrm{N} \text {-terminal methionine from } \\
\text { newly translated polypeptide chains }\end{array}$ & Bacteria, mammals, and yeast, plants & $\begin{array}{l}\text { Giglione et al., 2000; Odaka } \\
\text { and Kobayashi, } 2013\end{array}$ \\
\hline & Prolidase & $\begin{array}{l}\text { Cleavage of a peptide bond adjacent to a } \\
\text { proline residue }\end{array}$ & $\begin{array}{l}\text { Archaea (Pyrococcus furiosus), } \\
\text { bacteria, fungi, and plants }\end{array}$ & $\begin{array}{l}\text { Harrop and Mascharak, } \\
\text { 2013; Odaka and } \\
\text { Kobayashi, } 2013\end{array}$ \\
\hline & D-xylose isomerase & $\begin{array}{l}\text { Conversion of D-xylose and D-glucose into } \\
\text { D-xylulose and D-fructose, respectively }\end{array}$ & $\begin{array}{l}\text { Streptomyces diastaticus (an } \\
\text { alkaliphilic and thermophillic } \\
\text { bacterium) }\end{array}$ & Bhosale et al., 1996 \\
\hline & $\begin{array}{l}\text { Methylmalonyl-CoA } \\
\text { carboxytransferase }\end{array}$ & $\begin{array}{l}\text { Catalysis of carboxyl transfer between two } \\
\text { organic molecules, using two separate } \\
\text { carboxyltransferase domains. }\end{array}$ & $\begin{array}{l}\text { Propionibacterium shermanii } \\
\text { (Gram-positive bacterium) }\end{array}$ & $\begin{array}{l}\text { Odaka and Kobayashi, } \\
2013\end{array}$ \\
\hline & $\begin{array}{l}\text { Carbonic anhydrase or } \\
\text { carbonate dehydratase }\end{array}$ & $\begin{array}{l}\text { Catalysis of the conversion of } \mathrm{CO}_{2} \text { to } \mathrm{HCO}_{3}^{-} \\
\text {reversibly }\end{array}$ & Bacteria, fungi, algae, and plants & Jensen et al., 2020 \\
\hline & Carboxypeptidases & $\begin{array}{l}\text { Hydrolyzation of the C-terminal residues of } \\
\text { peptides and proteins and release free amino } \\
\text { acids individually }\end{array}$ & Animals, bacteria, fungi, and plants & Maret and Vallee, 1993 \\
\hline & Urease & $\begin{array}{l}\text { Catalysis of the seemingly simple hydrolysis of } \\
\text { urea into ammonia and carbamic acid }\end{array}$ & $\begin{array}{l}\text { Archaea, algae, bacteria, fungi, and } \\
\text { plants }\end{array}$ & Carter et al., 2009 \\
\hline & Aldehyde decarboxylase & Decarboxylation of aldehyde & Botryococcus braunii (green algae) & $\begin{array}{l}\text { Odaka and Kobayashi, } \\
2013\end{array}$ \\
\hline & Bromoperoxidase & Bromination & Bacteria & $\begin{array}{l}\text { Odaka and Kobayashi, } \\
2013\end{array}$ \\
\hline \multirow[t]{8}{*}{ Co transporters } & $\mathrm{NiCoT}$ & Transport of $\mathrm{Co}^{2+}$ and $\mathrm{Ni}^{2+}$ & Rhodococcus rhodochrous & $\begin{array}{l}\text { Odaka and Kobayashi, } \\
2013\end{array}$ \\
\hline & HupE/UreJ & Mediation of uptake of $\mathrm{Ni}^{2+}$ and $\mathrm{Co}^{2+}$ & Collimonas fungivorans & Eitinger, 2013 \\
\hline & CbiMNQO & $\begin{array}{l}\text { An energy-coupling factor (ECF) transporter for } \\
\mathrm{Ni}^{2+} \text { and } \mathrm{Co}^{2+}\end{array}$ & Salmonella enterica & Eitinger, 2013 \\
\hline & CorA & Transport system for $\mathrm{Mg}^{2+}$ and $\mathrm{Co}^{2+}$ & Thermotoga maritima & Eitinger, 2013 \\
\hline & IRT1 & Absorption of $\mathrm{Fe}^{2+}$ and $\mathrm{Co}^{2+}$ & Plants & $\begin{array}{l}\text { Korshunova et al., 1999; } \\
\text { Conte and Walker, } 2011\end{array}$ \\
\hline & FPN1 & Transport of $\mathrm{Fe}^{2+}$ and $\mathrm{Co}^{2+}$ to xylem & Plants & $\begin{array}{l}\text { Korshunova et al., 1999; } \\
\text { Conte and Walker, } 2011\end{array}$ \\
\hline & FPN2 & Transport of $\mathrm{Fe}^{2+}$ and $\mathrm{Co}^{2+}$ to vacuole & Plants & $\begin{array}{l}\text { Korshunova et al., 1999; } \\
\text { Conte and Walker, } 2011\end{array}$ \\
\hline & ARG1 & $\begin{array}{l}\text { An } \mathrm{ABC} \text { transporter to transporting } \mathrm{Ni}^{2+} \text { and } \\
\mathrm{Co}^{2+} \text { in chloroplast }\end{array}$ & Plants & Li et al., 2020 \\
\hline
\end{tabular}


and Methanomicrobiales, and cyanobacteria, like Anabaena, Nostoc, Toypothrix, and Anabaenopsis (Soumare et al., 2020). $\mathrm{N}_{2}$-fixing organisms are also classified into three categories: symbiotic, endophytic, and associated groups (Figure 1). Such classifications may not be accurate as some of them, such as those from Acetobacter and Azospirillum, could be associated, as well as endophytic bacteria.

\section{Cobalt Is Essential for Symbiotic Bacteria in $\mathrm{N}$ Fixation}

There are two major symbioses between $\mathrm{N}_{2}$-fixing bacteria and higher plants, one is rhizobia with leguminous plants and the other is Frankia with actinorhizal plants (Wall, 2000). The former involves more than 1,700 plant species in the family Fabaceae, which includes some economically important crops, such as alfalfa, beans, peas, and soybeans. More than 220 species are actinorhizal plants, which are mainly trees and shrubs forming symbiotic relationships with Frankia.

Rhizobia are gram-negative bacteria encompassing Rhizobium, Azorhizobium, Sinorhizobium, Bradyrhizobium, and Mesorhizobium (Table 2, Figure 1A). Co was identified to be essential for Rhizobium in the 1950s and 1960s (Ahmed and Evans, 1960; Reisenauer, 1960). Rhizobium uses nitrogenase to catalyze the conversion of $\mathrm{N}_{2}$ to $\mathrm{NH}_{3}$, which can be readily absorbed and assimilated by plants. Three enzymes, namely, methionine synthase, methyl malonyl-CoA mutase, and ribonucleotide reductase in Rhizobium and Bradyrhizobium species, are known to be cobalamin-dependent and significantly affect nodulation and $\mathrm{N}$ fixation. Early studies showed that four soybean seedlings inoculated with rhizobia supplemented with $1 \mu \mathrm{g} / \mathrm{L}$ Co were healthy and produced $25.3 \mathrm{~g}$ of dry weight. On the contrary, four rhizobia-inoculated seedlings devoid of $\mathrm{Co}$ encountered $\mathrm{N}$-deficiency symptoms and produced $16.6 \mathrm{~g}$ of dry weight, a $34.4 \%$ reduction in biomass due to the absence of Co (Ahmed and Evans, 1959). A close relationship was established amongst Co supply, cobalamin content in Rhizobium, leghemoglobin formation, $\mathrm{N}$ fixation, and plant growth (Kliewer and Evans, 1963a,b). The deficiency in Co significantly affects methionine synthase by reducing methionine synthesis, which subsequently decreases protein synthesis and produces smaller-sized bacteroids (bacteria in the nodules capable of $\mathrm{N}$ fixation) (Marschner, 2011). Methyl malonyl-CoA mutase catalyzes the production of leghemoglobin. If Co becomes limited, leghemoglobin synthesis is directly affected, resulting in reduced $\mathrm{N}$ fixation and ultimately a shortage of $\mathrm{N}$ supply. This is because leghemoglobin can protect nitrogenase from oxygen by limiting its supply (Hopkins, 1995). Ribonucleotide reductase is a cobalamin-dependent enzyme that catalyzes the reduction of ribonucleotides to deoxyribonucleotides, which is a rate-limiting step in DNA synthesis (Kolberg et al., 2004).

The genus Frankia is composed of gram-positive and gramvariable actinomycetes (Wall, 2000). It infects plants through root hairs and produces nodules in the pericycle. Frankia in nodules develops vesicles in which nitrogenase is suited (Huss-Danell, 1997). Co is needed for the synthesis of cobalamin which is in turn needed for $\mathrm{N}$ fixation. Actinomyceters are known as active producers of cobalamin (Hewitt and Bond, 1966). $\mathrm{N}$ fixation by actinorhizal plants appears to be comparable to the magnitude as that of the legumes (Wall, 2000).

Other symbioses occur in cyanobacteria with Gunnera and cycads. The genus Nostoc infected specialized gland organs located on the stems of Gunnera, such as G. chilensis and $G$. magellanica (Johansson and Bergman, 1994). Cyanobacteria also form symbiotic relationships with cycads in a special type of root system called coralloid roots (Chang et al., 2019). It has been welldocumented that cyanobacteria require Co for the biosynthesis of cobalamin (Cavet et al., 2003).

\section{Cobalt and Endophytic Bacteria in N Fixation}

A group of $\mathrm{N}_{2}$-fixing bacteria can form an endophytic relationship with many crop plants (Table 2, Figure 1B). By definition, any bacterium could be considered to be an endophytic diazotroph if (1) it can be isolated from surfacedisinfected plant tissue or extracted inside the plants, (2) it proves to be located inside the plant, either intra- or inter-cellularly by in-situ identification, and (3) it fixes $\mathrm{N}_{2}$, as demonstrated by acetylene reduction and/or ${ }^{15} \mathrm{~N}$-enrichment (Hartmann et al., 2000; Gupta et al., 2012). Common $\mathrm{N}_{2}$-fixing endophytic bacteria include Azoarcus spp. BH72 and Pseudomonas stutzeri A1501 in rice (Wang et al., 2016; Pham et al., 2017), Achromobacter spp. EMC1936 in tomato (Abdel-Rahman et al., 2017), Azospirillum lipoferum 4B in maize (Garcia et al., 2017), Burkholderia phytofirmans PsJN in grape plants (Compant et al., 2008), Enterobacter cloacae ENHKU01 in pepper (Santoyo et al., 2016), Gluconoacetobacter diazotrophicus PaI5 in sugarcane (James et al., 2001). Other bacteria, such as Herbaspirillum, Klebsiella, and Serratia also are implicated in $\mathrm{N}_{2}$ fixation (Rothballer et al., 2008; Franche et al., 2009). These bacteria possess either iron or vanadium nitrogenase that fixes $\mathrm{N}_{2}$ into $\mathrm{NH}_{3}$.

The complete genome of Azoarcus sp. BH72 (Krause et al., 2006), G. diazotrophicus PAl 5 (Bertalan et al., 2009), Herbaspirillum seropedicae SmR1 (Pedrosa et al., 2011), and S. marcesens RSC-14 (Khan et al., 2017) were sequenced. Among them, genomic and proteomic profiles of Azoarcus sp., Gluconoacetobacter diazotrophicus, Herbaspirillum seropedicae, and Serratia marcesens have been studied (Krause et al., 2006; Gupta et al., 2012). These bacteria have co-transport systems for $\mathrm{Co}^{2+}, \mathrm{Zn}^{2+}$, and $\mathrm{Cd}^{2+}$ or $\mathrm{Ca}^{2+}, \mathrm{Co}^{2+}, \mathrm{Zn}^{2+}$, and $\mathrm{Cd}^{2+}$ as well as putative receptors for vitamin $\mathrm{B}_{12}$. Comparative genomic analyses of $\mathrm{Ni}, \mathrm{Co}$, and vitamin $\mathrm{B}_{12}$ utilization showed that both metals are widely used by the bacteria and archaea, with the most common prokaryotic transporter being Cbi/NikMNQO. Ni-Fe hydrogenase, Ni-dependent urease, $\mathrm{B}_{12}$-dependent ribonucleotide reductase, methionine synthase, and methymalonly-CoA mutase are the most widespread metalloproteins for $\mathrm{Ni}$ and Co (Zhang et al., 2009). Thus, Co is needed by these bacteria.

\section{Cobalt and Plant Associated $\mathrm{N}_{2}$ Fixing Bacteria}

Associated $\mathrm{N}_{2}$-fixing bacteria include Azotobacter, Azospirillum, Beijerinckia, Burkholderia, Clostridium, Herbaspirillum, Gluconacetobacter, Methanosarcina, and Paenibacillus (Table 2, Figure 1C). These bacteria are associated with the roots of 
TABLE 2 | Representative nitrogen fixing bacteria.

\begin{tabular}{|c|c|c|c|}
\hline Type of association & Bacteria & Plants & References \\
\hline \multirow[t]{3}{*}{ Symbiosis } & Cyanobacteria & $\begin{array}{l}\text { Bryophyte symbiosis } \\
\text { Nostoc-Gunnera symbiosis } \\
\text { Azolla symbiosis } \\
\text { Cycad symbiosis } \\
\text { Lichen symbiosis }\end{array}$ & Adams et al., 2013 \\
\hline & $\begin{array}{l}\text { Rhizobia (Bradyrhizobium, } \\
\text { Burkholderia, Ensifer, and } \\
\text { Mesorhizobium) }\end{array}$ & Legume-Rhizobia symbiosis & Andrews and Andrews, 2017 \\
\hline & Frankia & $\begin{array}{l}\text { Non-legume-Frankia symbiosis: } \\
\text { Actinorhizal plants }\end{array}$ & Wall, 2000 \\
\hline Endophyte & $\begin{array}{l}\text { Azospirillum amazomense; Bacillus } \\
\text { spp.; Burkhoderia spp.; } \\
\text { Gluconacetobacter diazotrophicus; } \\
\text { Paenibacillus polymyxa; and } \\
\text { Pseudomonas aeruginosa }\end{array}$ & $\begin{array}{l}\text { Rice } \\
\text { Maize } \\
\text { Rice } \\
\text { Sugarcane } \\
\text { Maize } \\
\text { Wheat }\end{array}$ & $\begin{array}{l}\text { Puri et al., 2018; Rana et al., } \\
2020\end{array}$ \\
\hline \multirow[t]{2}{*}{ Association } & $\begin{array}{l}\text { Acetobacter nitrocaptans; } \\
\text { Azospirillum spp.; Bacillus } \\
\text { azotofixans; and Pseudomonas spp. }\end{array}$ & $\begin{array}{l}\text { Sugarcane association } \\
\text { Grasses and cereals (maize, } \\
\text { sorghum, wheat) } \\
\text { Grasses, sugarcane, wheat } \\
\text { Wetland rice }\end{array}$ & $\begin{array}{l}\text { Boddey and Dobereiner, 1988; } \\
\text { Rosenblueth et al., } 2018\end{array}$ \\
\hline & $\begin{array}{l}\text { Cyanobacteria; Acetobacter } \\
\text { diazotrophicus; Azoarcus spp.; } \\
\text { Azospirillum spp.; and Azotobacter } \\
\text { spp. }\end{array}$ & $\begin{array}{l}\text { Sugarcane } \\
\text { Grasses } \\
\text { Maize, wheat } \\
\text { Sugarcane }\end{array}$ & $\begin{array}{l}\text { Steenhoudt and Vanderleyden, } \\
2000\end{array}$ \\
\hline
\end{tabular}

a wide range of plants, including corn, rice, sugarcane, and wheat (Aasfar et al., 2021). Among them, the genus Azotobacter was first reported in 1901 and has been used as a biofertilizer thereafter (Gerlach and Vogel, 1902). Notable species found in soils are $A$. chroococcum, A. vinelandii, A. beigerinckii, A. armeniacus, A. nigricans, and A. paspali (Das, 2019). The genome of $A$. vinelandii DJ has been sequenced (Setubal et al., 2009). $\mathrm{N}$ fixation in these species is under aerobic conditions, and two-component proteins of Mo-dependent nitrogenase catalyze $\mathrm{N}_{2}$ into $\mathrm{NH}_{3}$. Co and vitamin $\mathrm{B}_{12}$ were found to be required by $A$. vinelandii OP. Additionally, 5,6dimethylbenzimidazolylcobamide coenzyme was identified in this species, which might play an important role in $\mathrm{N}$ fixation (Nicholas et al., 1962). Furthermore, higher concentrations of Co were needed for A. vinelandii to fix $\mathrm{N}_{2}$ than was needed for the utilization of ammonium compounds (Evans and Kliewer, 1964). Co at a concentration of $0.1 \mathrm{mg} / \mathrm{L}$ was reported to increase $\mathrm{N}$ fixation in $A$. chroococcum in Jensen's medium (Iswaran and Rao Sundara, 1964). Culture of A. chroococcum in half-strength $\mathrm{N}$-free Jensen's broth showed that $\mathrm{N}$ fixation was enhanced after supplemented with $\mathrm{Co}$ at $12.5 \mathrm{mg} / \mathrm{L}$ or $25 \mathrm{mg} / \mathrm{L}$ (Orji et al., 2018). Azotobacters were able to biosynthesize a series of vitamins, including $\mathrm{B}_{12}$ in chemically-defined media and dialyzed soil media (Gonzalez-Lopez et al., 1983; El-Essawy et al., 1984). In addition to A. vinelandii and A. chroococcum, Pseudomonas fluorescens, Bacillus megaterium, Bacillus firmus, and Sinorhizobium meliloti also produce cobalamin (Palacios et al., 2014), and the synthesized cobalamin may implicate the enhanced $\mathrm{N}$ fixation in these bacteria.
Azosprillum is another important genus of plant-associated $\mathrm{N}_{2}$-fixing bacteria. A. brasilense cultured on medium supplemented with $0.2 \mathrm{mM}$ Co was able to accumulate Co up to 0.1 to $0.6 \mathrm{mg}$ per gram of dry biomass (Kamnev et al., 2001). ${ }^{57}$ Co emission Mössbauer spectroscopy (EMS) studies of Co in Azospirillum brasilense Sp245 showed that Co activated glutamine synthetase to have two different Co forms at its active sites. In vitro, biochemical and spectroscopic analyses showed that $\mathrm{Co}^{2+}$ is among the divalent cations, along with $\mathrm{Mg}^{2+}$ and $\mathrm{Mn}^{2+}$, most effective in supporting the activity of glutamine synthetase at different adenylylation states, a key enzyme of $\mathrm{N}$ metabolism (Antonyuk et al., 2001).

\section{Nitrogen Fixing Bacteria and Crop Productivity}

Nitrogen is an essential macronutrient for plants. The application of synthetic $\mathrm{N}$ fertilizers has greatly enhanced crop production but also has caused serious environmental problems, such as groundwater contamination and surface water eutrophication (Hansen et al., 2017). As a result, exploring the potential of BNF becomes increasingly important. The symbiotic relationship between rhizobia and legume crops was considered the most important BNF system and estimated to contribute to 227 to $300 \mathrm{~kg} \mathrm{~N} /$ ha/year (Roughley et al., 1995; Herridge et al., 2008). $\mathrm{N}_{2}$ fixation by actinorhizal plants was estimated to be $240-350 \mathrm{~kg}$ N/ha/year (Wall, 2000).

Nitrogen fixation by plant-associated diazotrophs has been estimated to be $60 \mathrm{~kg} \mathrm{~N} /$ ha/year (Gupta et al., 2006; Reed et al., 2011). Moreover, the abundance of associated diazotrophs, such 


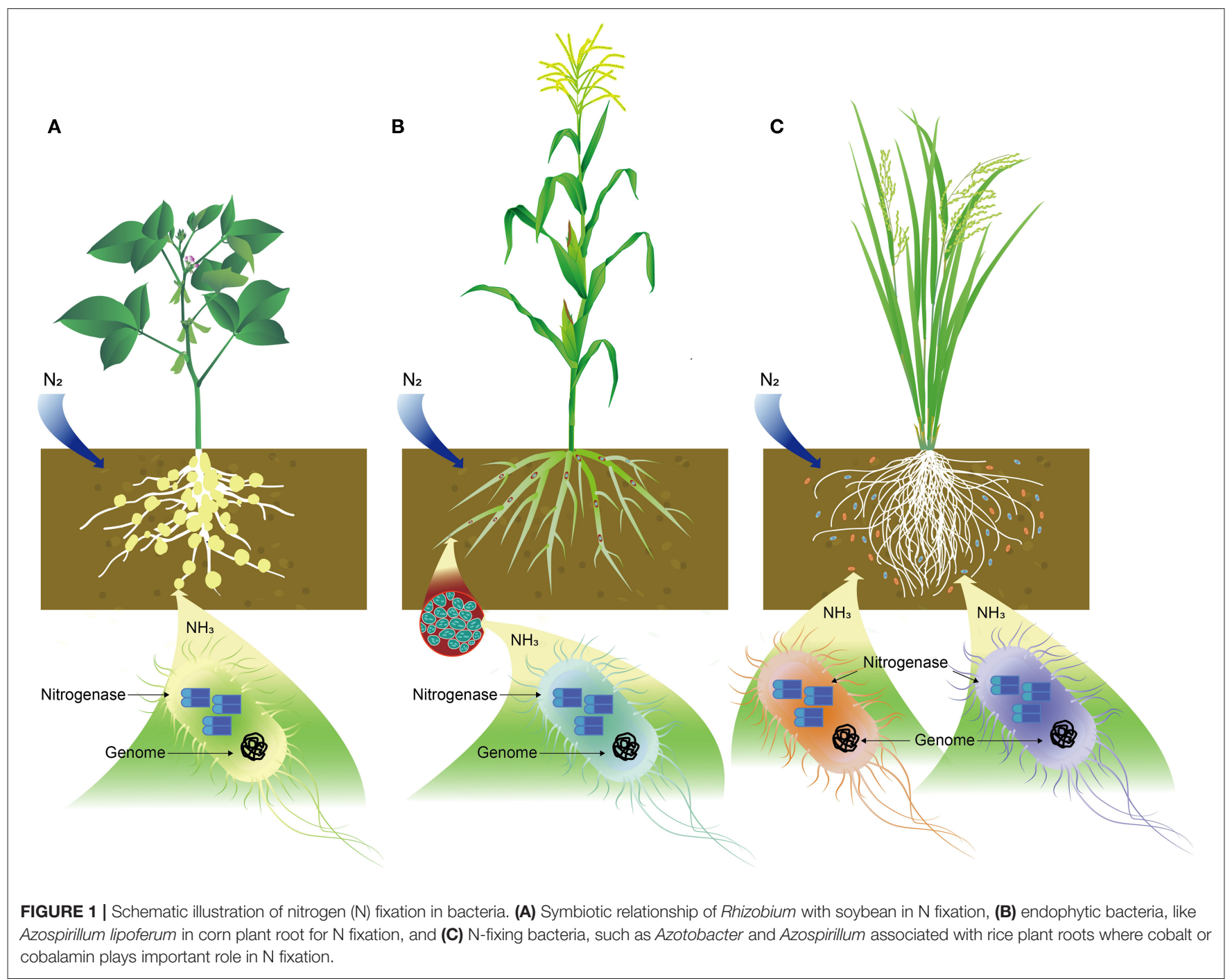

as Azotobacter species in the soil provides not only $\mathrm{N}$ (Din et al., 2019) but also phosphorus and plant growth regulators, which resulted in a yield increase of up to $40 \%$ in cereals and pulse crops (Yanni and El-Fattah, 1999; Choudhury and Kennedy, 2004; Kannan and Ponmurugan, 2010; Ritika and Dey, 2014; Wani et al., 2016; Velmourougane et al., 2019). Such beneficial effects have been harnessed ecologically in the engineering of Azotobacter species for fixing plant needed $\mathrm{N}$, while reducing the reliance on synthetic $\mathrm{N}$ fertilizers for crop production in an environmentally friendly manner (Wani et al., 2016; Bageshwar et al., 2017; Ke et al., 2021).

Endophytic bacteria also contribute significantly to $\mathrm{N}$ input. Azoarcus is an endophytic $\mathrm{N}_{2}$-fixing diazotroph, and its action in roots of kallar grass increased hay yield up to 20-40 t/ha/year without $\mathrm{N}$ fertilizer application in salinesodic, alkaline soils (Hurek and Reinhold-Hurek, 2003). Gluconoacetobacter diazotrophicus (Acetobacter diazotrophicus) is the main contributor in sugarcane and can fix up to $150 \mathrm{~kg}$ N/ha/year (Dobereiner et al., 1993; Muthukumarasamy et al., 2005). Many C-4 energy plants, such as Miscanthus sacchariflorus, Spartina pectinate, and Penisettum purpureum can harbor endophytic bacteria, which support the $\mathrm{N}$ requirement of these plants (Kirchhof et al., 1997). Gupta et al. (2012) reported that $\mathrm{N}$ derived from the air by endophytic bacteria for rice ranged from 9.2 to $47 \%$ depending on bacterial species. These results indicate that endophytic diazotrophs have a great potential to enhance the productivity of non-leguminous crops.

The aforementioned bacteria essentially act as the same as gut bacteria in mammals by living between plant cells as endophytes, close association with roots, or symbiotically and become indispensable for plant growth and development. Microorganisms are associated with all plant organs (Wei et al., 2017), but roots have the largest number and greatest range of microbes. Thus, a plant growing under field conditions is a community, not an individual. Such associations are collectively termed "phytomicrobiome." The phytomicrobiome is integral for plant growth and function. Microbes play important roles in plant nutrient acquisition, biotic and abiotic stress management, 
physiology regulation through microbe-to-plant signals, and growth regulation via the production of phytohormones. The foregoing discussion documents the role of Co plays in $\mathrm{N}_{2}$ fixing rhizosphere bacteria. If we accept that coevolution exists between microbes and plants and the phytomicrobione in general, Co should be considered as an essential element to plants as it is required by symbiotic, endophytic, and associated bacteria.

\section{COBALT COENZYMES AND PROTEINS}

Cobalamin is a cofactor of adenosylcobalamin-dependent isomerases, ethanolamine ammonia-lyase, methylcobalamindependent methyltransferase, and ribonucleotide reductase in animals and bacteria (Table 1). Co is also a cofactor of non-corrin coenzymes or metalloproteins including aldehyde decarboxylase, bromoperoxidase-esterase, D-xylose isomerase, methionine aminopeptidase (MA), methylmalonyl-CoA carboxytransferase, nitrile hydratase (NHase), prolidase, and thiocyanate hydrolase (THase) in animals, bacteria, and yeasts. However, cobalamin-dependent enzymes or Co-proteins in plants remain obscure.

\section{Cobalt Proteins in Plants}

There are several lines of evidence suggesting that plants may have cobalamin-dependent enzymes and Co-containing proteins: (1) The ancestor of the chloroplast is cyanobacteria (Falcón et al., 2010), and Co is required by this group of bacteria. The speculation is that Co may be needed by plants. (2) Plants have been documented to utilize cobalamin produced by symbiotic, endophytic, and associated $\mathrm{N}_{2}$ fixing bacteria. Cobalamin concentrations of 37,26 , and $11 \mu \mathrm{g} / 100 \mathrm{~g}$ dry weight were detected in Hippophae rhammoides, Elymus, and Inula helenium, respectively (Nakos et al., 2017). There is a possibility that cobalamin-dependent enzymes may occur in plants. Poston (1977) reported the identification of leucine 2,3aminomutase in extracts of bean seedlings. Its activity was stimulated by coenzyme $\mathrm{B}_{12}$ but inhibited by unknown factors. The inhibition was removed by the addition of $\mathrm{B}_{12}$, suggesting the presence of a cobalamin-dependent enzyme in higher plants. Subsequently, two coenzyme $\mathrm{B}_{12}$-dependent enzymes: leucine 2,3-aminomutase and methylmalonyl-CoA mutase were reported in potato tubers (Poston, 1978), but methylmalonylCoA mutase was found to be a phosphatase (Paizs et al., 2008). (3) Co is required by lower plants, which is to be discussed in the following section. (4) Plants can take up and transport cobalamin (Mozafar, 1994; Sato et al., 2004). A recent study using fluorescent analogs to follow the uptake and transport of cobalamin showed that Lepidium sativum can absorb cobalamin (Lawrence et al., 2018). Seed priming with cobalamin provided significant protection against the salt stress of common beans (Keshavarz and Moghadam, 2017). The incorporation of Co in plant tissue culture media significantly improves plantlet production (Bartolo and Macey, 1989). (5) Co as a metal cofactor of some additional enzymes and proteins are briefly discussed below (Table 1).

Carbonic anhydrase or carbonate dehydratase (CA, EC: 4.2.1.1) is a metalloenzyme catalyzing the conversion of $\mathrm{CO}_{2}$ to $\mathrm{HCO}_{3}^{-}$reversibly in many organisms including plants, particularly $\mathrm{C}_{4}$ and CAM plants. Eight different CA classes have been described as $\alpha-, \beta-, \gamma_{-}, \delta_{-}, \zeta_{-}, \eta_{-}, \theta-$, and a recently described $\iota$-CA in microalgae. The metalloenzymes commonly use $\mathrm{Zn}^{2+}$ as a metal cofactor. However, $\mathrm{Zn}^{2+}$ in $\gamma$ class can be replaced by $\mathrm{Co}^{2+}$ and $\mathrm{Fe}^{2+}$ in prokaryotes, fungi, algae, and plants, but in $\delta$ class is only can be replaced by $\mathrm{Co}^{2+}$ in marine phytoplankton (Jensen et al., 2020).

Carboxypeptidases (CPSs, EC: 3.4.16-3.4.18) are proteases hydrolyzing the C-terminal residues of peptides and proteins and release free amino acids individually. CPSs are divided into serine (EC: 3.4.16), metal (EC: 3.4.17), and cysteine (EC: 3.4.18) and occur in animals, bacteria, fungi, and plants. One $\mathrm{Zn}$ atom is essential to the catalytic activity of native carboxypeptidase A. $\mathrm{Zn}$ can be removed by dialysis at low $\mathrm{pH}$ or with chelating agents at neutral $\mathrm{pH}$, which results in the inactivation of the enzyme. The re-addition of the metal restores the dual activities of carboxypeptidase toward peptides and esters. Co was found to be more active than $\mathrm{Zn}$ in the enzyme toward peptides and has nearly the same activity toward esters, indicating that Co in the active site is virtually identical to that of $\mathrm{Zn}$ in the native enzyme (Maret and Vallee, 1993).

Methionine aminopeptidase (MAP, EC 3.4.11.18) is widely documented in animals, bacteria, yeast, and plants. It is a Codependent enzyme responsible for the cleavage of the N-terminal methionine from newly translated polypeptide chains. Two classes of MAPs (MAP1 and MAP2) were reported in bacteria, and at least one MAP1 and one MAP2 occur in eukaryotes (Giglione and Meinnel, 2001). In Arabidopsis, there are four MAP1s (MAP1A, MAP1B, MAP1C, and MAP1D) and two MAP2s (MAP2A and MAP2B), along with two class 1 peptide deformylases (PDF1A and PDF1B). The plant MAP proteins show significant similarity to the eubacterial counterparts except for MAP1A and two MAP2s. It has been documented that the substrate specificity of PDFs and both organellar and cytosolic MAPs in plants are similar to that of their bacterial counterparts (Giglione et al., 2000). The MAP from Salmonella typhimurium is stimulated only by $\mathrm{Co}^{2+}$, not by $\mathrm{Mg}^{2+}, \mathrm{Mn}^{2+}$, or $\mathrm{Zn}^{2+}$ and is inhibited by metal ion chelator EDTA. E. coli MAP is a monomeric protein of $29 \mathrm{kDa}$ consisting of 263 residues that possess two $\mathrm{Co}^{2+}$ ions in its active site (Permyakov, 2021).

Prolidase (PEPD, EC 3.4.13.9) hydrolyze peptide bonds of imidodipeptides with C-terminal proline or hydroxyproline, thus liberating proline. PEPD has been identified in fungi, plants (Kubota et al., 1977), archaea, and bacteria. The preferable substrate requires metal ions $\mathrm{Mn}^{2+}, \mathrm{Zn}^{2+}$, or $\mathrm{Co}^{2+}$.

Peroxidases are isoenzymes present in all organisms, which catalyze redox reactions that cleave peroxides; specifically, it breaks down hydrogen peroxide. The study of Han et al. (2008) found that $\mathrm{Co}^{2+}$ at a concentration below $0.1 \mathrm{mM}$ increased horseradish peroxidase activity because $\mathrm{Co}^{2+}$ binds with some amino acids near or in the active site of the enzyme.

Urease is an enzyme occurring in selected archaea, algae, bacteria, fungi, and plants. It catalyzes the hydrolysis of urea into ammonia and carbamic acid. The active site of urease contains two $\mathrm{Ni}^{2+}$ atoms that are bridged by a carbamylated lysine residue and a water molecule (Carter et al., 2009). The study of Watanabe 
et al. (1994) reported that urease activity of cucumber leaves was markedly reduced when $\mathrm{Ni}$ concentration became $<100$ ng/L, but supplementing Co restored urase activity. Additionally, urease was also activated by both $\mathrm{Co}$ and manganese (Mn) through in vitro assay (Carter et al., 2009).

Cobalt transporters. Transporters specifically for Co have not been reported. The current understanding is that Co can be transported through Fe transporters (Figure 2). In Arabidopsis thaliana, Co is taken up from the soil into epidermal cells of roots by IRON-REGULATED TRANSPORTER 1 (IRT1), which is commonly known for absorption of Fe (Korshunova et al., 1999). Once Co is absorbed inside cells, Ferroportins, FPN1, and FPN2 are responsible for its further movement. IREG1/FPN1 is localized to the plasma membrane and expressed in the steel, indicating it is responsible for the loading of Fe to xylem, and FPN2 is situated the in vacuolar membrane and involved in buffering Fe concentration in the cytosol (Morrissey et al., 2009). Truncated FPN2 causes an elevated level of Co in shoots, while the loss of FPN1 abolishes Co accumulation in shoots. A double mutant of $f p n 1 f p n 2$ is unable to sequester Co in root vacuole and cannot transport Co to shoots. These results suggest that Co is likely absorbed and transported in the same way as $\mathrm{Fe}$ in plants (Figure 2). Additionally, an ATP-binding cassette (ABC) transporter from Arabidopsis has also been reported to transport $\mathrm{Co}, \mathrm{Ni}$, and $\mathrm{Pb}$ (Morel et al., 2009). Co movement in leaves is also associated with $\mathrm{Ni}$, and $\mathrm{Ni}$ and Co movement in or out of chloroplasts are through an $\mathrm{ABC}$ transporter in the mediation of ionic homeostasis in the chloroplast of rice (Li et al., 2020).

\section{Cobalt Substitution of Other Metals}

A characteristic of $\mathrm{Co}$ is its ability to substitute for other transition metals in a large number of enzymes. Maret and Vallee (1993) listed 37 Co-substituted metalloproteins, of which 24 are native to $\mathrm{Zn}$, nine to copper $(\mathrm{Cu})$, and four to Fe. These enzymes mainly occur in animals, bacteria, and yeast, while a few are in plants. Such a characteristic is closely related to the properties of Co with other metals. The ionic radius of $\mathrm{Co}^{2+}$ is $0.76 \AA$, which is similar to $0.74 \AA$ of $\mathrm{Zn}^{2+}, 0.69 \AA$ for $\mathrm{Cu}^{2+}$, and $0.76 \AA$ for $\mathrm{Fe}^{2+}$. Additionally, based on the available Protein Data Bank structures with $\mathrm{Co}^{2+}$, the study Khrustalev et al. (2019) found that $\mathrm{Co}^{2+}$ is commonly bound by cation traps. The traps are formed by relatively negatively charged regions of random coil between a $\beta$ stand and $\alpha$ helix and between two $\beta$ strands in which His, Asp, and Glu residues are situated. On the other hand, these sites are also occupied by other metals ions, such as $\mathrm{Cu}^{2+}, \mathrm{Mg}^{2+}$, $\mathrm{Mn}^{2+}$, and $\mathrm{Zn}^{2+}$, which play significant roles as catalysts. As a result, $\mathrm{Co}^{2+}$ could rather readily substitute for these ions in the active sites of enzymes. Additionally, based on the FIND-SITEmetal, a program for the prediction of the metal-binding site, the study of Brylinski and Skolnick (2011) found that $\mathrm{Zn}$, due to a lower coordination number preference, is typically chelated with Cys and His, and His residues have a strong preference for $\mathrm{Co}, \mathrm{Cu}, \mathrm{Fe}, \mathrm{Ni}$, and $\mathrm{Zn}$ atoms. Thus, $\mathrm{Co}$ is able to replace $\mathrm{Cu}$, $\mathrm{Fe}, \mathrm{Ni}$, and $\mathrm{Zn}$ in the active sites of enzymes. For example, Co addition alleviated $\mathrm{Zn}$ limitation in production of Thalassiosira weissflogii, which was due to Co substitution of $\mathrm{Zn}$ in the main isoform of carbonic anhydrase (Yee and Morel, 1996). Co substitution of $\mathrm{Zn}$ was also reported in two northeast Pacific isolates of diatoms Pseudo-nitzschia delicatissima UNC1205 and Thalassiosira spp. UNC1203 (Kellogg et al., 2020). $\mathrm{Co}^{2+}$ has been used as a spectroscopically active substitute for $\mathrm{Zn}^{2+}$ in enzymes (Bennett, 2010). Substitution of tetrahedral $\mathrm{Zn}^{2+}$ by highercoordinate $\mathrm{Co}^{2+}$ often results in a catalytically active species, sometimes with catalytic properties perhaps unexpectedly similar to those of the native enzyme. In the vast majority of cases, no other transition ion than $\mathrm{Co}^{2+}$ provides a better substitute for $\mathrm{Zn}^{2+}$ (Maret and Vallee, 1993; Bennett, 2010). Due to these reasons, Co specific enzymes or proteins have not been conclusively identified. With the advance of omics, functions of a large number of gene sequences have not been assigned. Using the FIND-SITE-metal, a program developed for prediction of the metal-binding site, Brylinski and Skolnick (2011) predicted that about 10,953 putative metal-binding proteins in human proteome were bound with $\mathrm{Ca}, 10,534$ bound with $\mathrm{Mg}, 8,681$ with $\mathrm{Zn}, 1,863$ with $\mathrm{Fe}, 1,246$ with Mn, 652 with Co, 476 with $\mathrm{Cu}$, and 403 with $\mathrm{Ni}$. The predicted binding proteins with Co are greater than $\mathrm{Cu}$ and $\mathrm{Ni}$ in humans. Based on this assignment in the human proteome, it could be extremely difficult to believe that there are no Co-containing enzymes and proteins in plants.

\section{COBALT IS ESSENTIAL FOR LOWER PLANTS}

Lower plants are commonly known as non-vascular plants because they do not have xylem and phloem vascular systems. Non-vascular plants are generally divided into bryophytes and algae.

\section{Bryophytes}

Bryophytes are seedless plants including Anthocerotophyta (hornworts), Bryophyta (mosses), and Marchantiophyta (liverworts) (Davies et al., 2020). This group of plants is able to absorb Co from air, soil, and water. In an early geochemical survey performed in Wisconsin and adjacent states and Missouri and Kentucky in the US, the study of Shacklette (1965) documented that the mean concentration of Co in 38 samples of liverworts and mosses was $32 \mathrm{mg} / \mathrm{kg}$, and the concentration in the lower plants was closely related to the amount of the element in the soil, suggesting they act as a bioindicator of Co concentration in the environment (Baker, 1981). Mosses sampled from streams of the Idaho Cobalt Belt (U.S.) showed that Co concentrations in the plants almost perfectly correlated with those in the sediments, and the maximum content of Co $(2,000 \mathrm{mg} / \mathrm{kg})$ in moss ash corresponded to the maximum concentration of 320 $\mathrm{mg} / \mathrm{kg}$ in the sediment (Erdman and Modreski, 1984). Mosses, such as Bryum argenteum and Hypnum cupressiforme were also considered to be bioindicators for monitoring heavy metal contamination in the air (Andić et al., 2015). Interestingly, the accumulation of Co did not cause any physiological damages to plants, but their growth was further enhanced.

The ability to take up Co could be related to the nonvascular nature and unidentified transporter. A radiolabel study showed that the total amount of ${ }^{60} \mathrm{Co}$ accumulated 


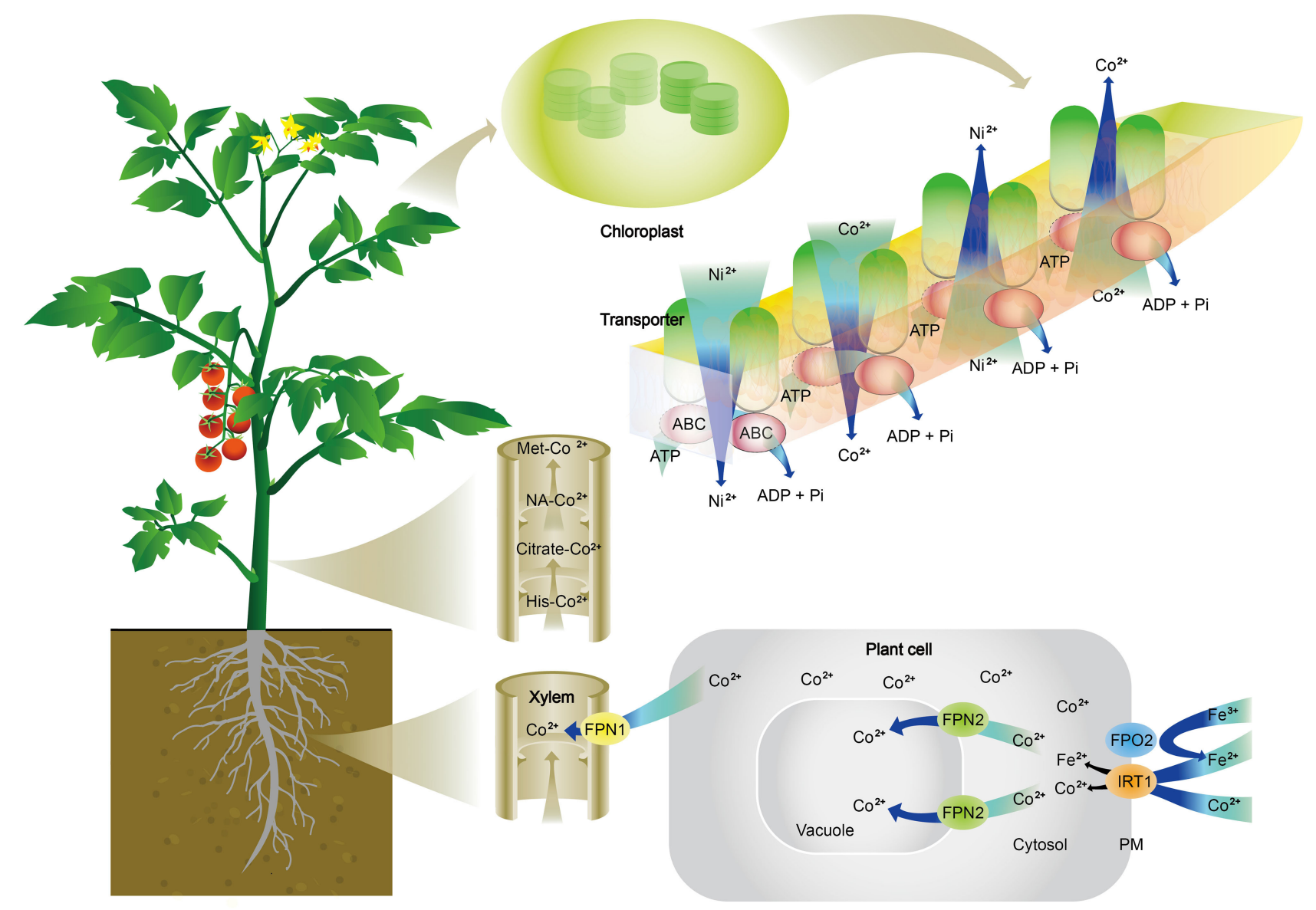

FIGURE 2 | Schematic illustration of cobalt $\left(\mathrm{Co}^{2+}\right)$ absorption, transport, and distribution in plants. $\mathrm{Co}^{2+}$ is absorbed from the soil into epidermal cells of roots by an iron transporter (IRT1). Once $\mathrm{Co}^{2+}$ is absorbed inside cells, Ferroportins (FPN1 and FPN2) are responsible for its further movement. FPN2 transports Co ${ }^{2+}$ into vacuoles, resulting in the sequestration of $\mathrm{Co}$ in root cells. FPN1 is to load $\mathrm{Co}^{2+}$ into the xylem. In the xylem, $\mathrm{Co}^{2+}$ is complexed with citrate, histidine (His), methionine (Met), or nicotianamine (NA) to be translocated to shoots. $\mathrm{Co}^{2+}$ is released in leaves and participate in metabolisms, which are often associated with nickel (Ni) and iron (Fe). It is shown here the Ni and Co movement in or out of chloroplasts through ATP-binding cassette (ABC) transporter in the mediation of ionic homeostasis in the chloroplast.

in $P$. commune and $D$. scoparium under given conditions were 7.1 and $6.1 \mathrm{mg} / \mathrm{kg}$, respectively. More than $95 \%$ of ${ }^{60}$ Co in D. scoparium was localized extracellular, while $70 \%$ of ${ }^{60} \mathrm{Co}$ in $P$. commune was localized extracellular and about 20\% localized intracellularly. These results showed that Co was largely adsorbed extracellularly, and there were unidentified transporters regulating the transport of Co into intracellular sites.

The enhanced growth could be in part attributed to the symbiotic relationship with cyanobacteria. Some bryophytes, primarily liverworts, and hornworts can form a symbiosis with cyanobacteria, such as Nostoc spp. After infection, Nostoc underwent some morphological and physiological changes by reducing growth rate and $\mathrm{CO}_{2}$ fixation but enhancing the fixation of $\mathrm{N}_{2}$ as well as releasing fixed $\mathrm{N}$ compounds to the plants. Cyanobacteria, like rhizobia, require cobalamin as a cofactor for nitrogenase complex to fix $\mathrm{N}_{2}$ (Böhme, 1998). Thus, cyanobacteria-bryophyte symbioses require Co.

\section{Algae}

Algae constitute a polyphyletic group ranging from unicellular microalgae, like chlorella and diatoms to multicellular forms, such as the giant kelp, seaweeds, and charophytes (Barsanti and Gualtieri, 2006). Co is essential to some marine algal species, including charophyte, diatoms, and dinoflagellates (Nagpal, 2004). Green alga Chlorella salina exhibited two phases of uptake of $\mathrm{Co}^{2+}$ (Garnham et al., 1992). The initial phase was rapid and independent of metabolism, and the second phase was slow and dependent on metabolism. Competition studies showed that the $\mathrm{Co}^{2+}$ uptake system was different from that for $\mathrm{Mg}^{2+}, \mathrm{Mn}^{2+}$, and $\mathrm{Zn}^{2+}$. The greatest amount of Co was associated with the cell wall. Co concentrations in the cytosol were $0.17 \mathrm{mM}$ but $2.89 \mathrm{mM}$ in the vacuole, suggesting that Co transport was well-controlled in C. salina. In the work of Czerpak et al. (1994), they studied the responses of a freshwater green alga Chlorella pyrenoidosa to different levels of Co and found that Co in a range from 5 to $50 \mathrm{mM}$ significantly enhanced the growth of Chlorella pyrenoidosa, including 150-160 and 50-60\% 
increase in fresh and dry weights, respectively. Such increase was related to the increase of chlorophylls $a$ and $b$ by $45-$ $65 \%$, water-soluble proteins by $19-20 \%$, total carotenoids $55-$ $65 \%$, and monosaccharides content 55-60\%, when compared with the culture devoid of Co. Although mechanisms behind the stimulating effects have not been elucidated, it is likely due to the biosynthesis of cobalamin that enhanced alga growth. Two cobalamin coenzyme $5^{\prime}$-deoxyadenosylcobalamin and methylcobalamin occurred in green alga C. vulgaris, and the addition of cobalamin significantly stimulated green alga growth (Watanabe et al., 1997). Moreover, C. vulgaris grown in Bold's basal medium supplemented with 2 and $2.5 \mu \mathrm{M} \mathrm{CoCl}_{2}$ produced 166.23 and $173.32 \mu \mathrm{g}$ vitamin $\mathrm{B}_{12}$ per $100 \mathrm{~g}$ dry weight (Jalilian et al., 2019). Additionally, many algal species require different combinations of cobalamin, vitamin $\mathrm{B}_{1}$, and $\mathrm{B}_{7}$ (Croft et al., 2005) as they do not have pathways to synthesize cobalamin or may use alternative cobalamin-independent routes bypassing the need for the vitamin (Cruz-Lopez and Maske, 2016; Yao et al., 2018). As Co is a constituent of cobalamin, Co is required by those algae.

Some algal species, such as those in the genera Coccomyxa and Elliptochloris as well as diatoms form symbiotic relationships with cyanobacteria (Grube et al., 2017). Co is required for the growth of cyanobacteria, such as Anabaenza cylindrica Lemm (Holm-Hansen et al., 1954) and Prochlorococcus (Hawco et al., 2020) as they need it for $\mathrm{N}$ fixation in specialized cells called heterocysts. Thus, algal species symbiotic with cyanobacteria require $\mathrm{Co}$ for $\mathrm{N}$-fixation.

\section{COBALT IMPROVES THE GROWTH OF HIGHER PLANTS}

Cobalt content in the crust of the earth ranges from 15 to 30 $\mathrm{mg} / \mathrm{kg}$ (Roberts and Gunn, 2014). Co in soils is closely related to the weathering of parental minerals, such as cobaltite, smaltite, and erythrite (Bakkaus et al., 2005) as well as Co pollution (Mahey et al., 2020). Co in the surface soils of the world varies from 4.5 to $12 \mathrm{mg} / \mathrm{kg}$ with the highest level occurring in heavy loamy soils and the lowest in organic and light sandy soils (Kabata-Pendias and Mukherjee, 2007). However, Co in reference soil samples was found to differ from 5.5 to $29.9 \mathrm{mg} / \mathrm{kg}$ in the United States (U.S.) and 5.5 to $97 \mathrm{mg} / \mathrm{kg}$ in Chinese soils (Govindaraju, 1994). PilonSmits et al. (2009) suggested that soil Co concentrations generally range from 15 to $25 \mathrm{mg} / \mathrm{kg}$.

\section{Cobalt in Higher Plants}

Plants absorb Co. Table 3 lists Co concentrations in over 140 non-hyperaccumulating species ranging from 0.04 to $274 \mathrm{mg} / \mathrm{kg}$. Average concentrations of Co in grasses vary from 60 to 270 $\mu \mathrm{g} / \mathrm{kg}$ and in clover differ from 100 to $570 \mu \mathrm{g} / \mathrm{kg}$ across Australia, Finland, Germany, Great Britain, Japan, New Zealand, Poland, Sweden, and the US (Kabata-Pendias and Mukherjee, 2007). Legumes absorb more Co than grasses. Plants that accumulate metals to a level 100 -fold higher than those typically recorded in common plants are known as hyperaccumulators (Brooks, 1998).

As discussed above, Co specific transporters have not been reported, and a schematic diagram for Co absorption and translocation is presented in Figure 2. After absorption by roots, Co is either sequestrated in the vacuole of root cells or transported to shoots. Co that is being transported to shoots is chelated with ligands. Co has little affinity with phytochelatins (Chen et al., 1997; Cheng et al., 2005), thus the ligands are not likely Co-S bonds. The study by Collins et al. (2010) reported that $\mathrm{Co}^{2+}$ was complexed with carboxylic acids, which were transported from roots to shoots in wheat or tomato plants. Other ligands are citrate or malate as well as non-proteinogenic amino acids, such as histidine and nicotianamine (Figure 2). Co has low mobility within the leaf tissue and is largely distributed in the vascular system of tomato and wheat leaves (Collins et al., 2010). Co transport from roots to shoots is well-controlled. Using radiolabeled ${ }^{57} \mathrm{Co}$, Page and Feller (2005) studied Co transport in wheat plants and found that $80 \%$ of ${ }^{57}$ Co remained in roots after 4 days of culture, and $50 \%$ was retained in the roots after 50 days; during which, some ${ }^{57}$ Co moved to the apical part of the main roots, suggesting that the loading of Co to the xylem is well-controlled, probably by FPN1 in wheat plants. In another study, Collins et al. (2010) reported that tomato and wheat plants grown in a nutrient solution containing $2.94 \mathrm{mg} / \mathrm{L}$ Co had $4,423 \mu \mathrm{g} / \mathrm{kg}$ and $9,319 \mu \mathrm{g} / \mathrm{kg}$ of Co in roots, respectively; but shoot concentrations of Co were $1,581 \mu \mathrm{g} / \mathrm{kg}$ and 395 $\mu \mathrm{g} / \mathrm{kg}$, respectively. This means that $35.7 \%$ of Co absorbed by tomato and $4.2 \%$ of Co absorbed wheat plants were transported from roots to shoots. Furthermore, for the $1,581 \mu \mathrm{g} / \mathrm{kg}$ Co in tomato shoots, $846 \mu \mathrm{g} / \mathrm{kg}$ was in the stem, $492 \mu \mathrm{g} / \mathrm{kg}$ in old leaves, only $243 \mu \mathrm{g} / \mathrm{kg}$ in young leaves, indicating that only $5.5 \%$ of absorbed Co is transported to actively growing shoots of tomato plants. These transport patterns are like those of titanium (Lyu et al., 2017) which are strictly controlled by plants. These findings imply that plants probably have unidentified transporters specifically for the transport of Co. Due to its toxicity at higher concentrations, the rigorous control of the transport and distribution would ensure that only an appropriate amount of Co could be transported to actively growing shoots. On the other hand, why was more Co transported to dicot tomato shoots than monocot wheat shoots? One explanation could be that different plants have different ligands for complexing Co, and Co complexed by ligands in tomato was more mobile than that in wheat. Another explanation could be that tomato plants need more Co to fulfill some unidentified roles in shoots. Further research is needed to verify these propositions.

To maintain ionic homeostasis in shoots, particularly in chloroplasts, plants develop mechanisms to mediate Co in chloroplasts. An ARG1 transporter, belonging to the ATPbinding cassette, was identified in rice (Li et al., 2020), which was able to modulate the levels of $\mathrm{Co}$ and $\mathrm{Ni}$ in chloroplasts to prevent excessive $\mathrm{Co}$ and $\mathrm{Ni}$ from competing with metal cofactors in chlorophyll and metal-binding proteins in photosynthesis (Figure 2). 
TABLE 3 | The concentration of cobalt in higher plants with the exclusion of cobalt hyperaccumulators.

\begin{tabular}{|c|c|c|c|c|c|}
\hline Family & Species & Common name & Plant organ & Content $(\mathrm{mg} / \mathrm{kg})$ & References \\
\hline Acanthaceae & Lophostachys villosa Pohl & Lophostachys & Leaves & 31.00 & Van der Ent and Reeves, 2015 \\
\hline Adiantaceae & Taenitis blechnoides (Willd.) Sw. & Ribbon fern & Leaves & 22.00 & Van der Ent and Reeves, 2015 \\
\hline Amaranthaceae & Pfaffia sarcophylla Pedersen & Pfaffia & Leaves & 13.00 & Van der Ent and Reeves, 2015 \\
\hline Anacardiaceae & Gluta wallichii (Hook.f.) Ding Hou & Gluta & Leaves & 5.00 & Van der Ent and Reeves, 2015 \\
\hline Apocynaceae & Carissa spinarum L. & Bush plum & $\begin{array}{l}\text { Stems, leaves and } \\
\text { flowers }\end{array}$ & 1.60 & Rajakaruna and Bohm, 2002 \\
\hline Arecaceae & Phoenix farinifera Roxb. & Ceylon date palm & Whole plants & 0.04 & Rajakaruna and Bohm, 2002 \\
\hline Aristolochiaceae & Thottea triserialis Ding Hou & Thottea & Leaves & 5.00 & Van der Ent and Reeves, 2015 \\
\hline Asparagaceae & Asparagus zeylanicus Hook.f. & Asparagus & Whole plants & 0.90 & Rajakaruna and Bohm, 2002 \\
\hline Berberidaceae & Podophyllum peltatum L. & May-apple & Shoots & 0.60 & Koleli et al., 2015 \\
\hline Betulaceae & Betula pubescens Ehrh. & Birch & Leaves & 0.36 & Reimann et al., 2001 \\
\hline Bignoniaceae & Zeyheria digitalis (Vell.) Hoehne and Kuhlm & Zeyheria & Leaves & 2.00 & Van der Ent and Reeves, 2015 \\
\hline Blechnaceae & Blechnum borneense C.Chr. & Hard fern & Leaves & 10.00 & Van der Ent and Reeves, 2015 \\
\hline Boraginaceae & Anchusa granatensis Boiss. & Anchusa & Shoots & 0.90 & Koleli et al., 2015 \\
\hline Boraginaceae & $\begin{array}{l}\text { Onosma bracteosum Hausskn. and } \\
\text { Bornm. }\end{array}$ & Onosma & Shoots & 6.60 & Koleli et al., 2015 \\
\hline Brassicaceae & Alyssum minus (L.) Rothm. & Wild Alyssum & Shoots & 1.20 & Koleli et al., 2015 \\
\hline Brassicaceae & Alyssum murale Waldst. and Kit. & Yellowtuft & Shoots & 7.70 & Koleli et al., 2015 \\
\hline Brassicaceae & Aurinia saxatilis (L.) Desv. & Basket of gold & Roots & 37.00 & Homer, 1991 \\
\hline Chrysobalanaceae & Parinari elmeri Merri. & Parinari & Leaves & 138.00 & Van der Ent and Reeves, 2015 \\
\hline Clusiaceae & Mesua paniculate (L.) Jack & Chinese box & Leaves & 77.00 & Van der Ent and Reeves, 2015 \\
\hline Compositae & Epaltes divaricate (L.) Cass. & Narrow-Leaf epaltes & Whole plants & 15.60 & Rajakaruna and Bohm, 2002 \\
\hline Convolvulaceae & Evolvulus alsinoides L. & Little glory & Whole plants & 17.10 & Rajakaruna and Bohm, 2002 \\
\hline Convolvulaceae & Jacquemontia sp. & Clustervine & Leaves & 16.00 & Van der Ent and Reeves, 2015 \\
\hline Cornaceae & Nyssa aquatica L. & Water tupelo & Leaves & 156.00 & McLeod and Ciravolo, 2007 \\
\hline Cornaceae & Nyssa aquatica L. & Water tupelo & Leaves & 24.50 & Wallace et al., 1982 \\
\hline Cornaceae & Nyssa sylvatica Marsh. & Black gum & Mature foliage & 27.20 & Thomas, 1975 \\
\hline Cornaceae & Nyssa sylvatica var. biflora (Walt.) Sarg. & Black gum & Leaves & 267.00 & McLeod and Ciravolo, 2007 \\
\hline Cyperaceae & Fimbristylis falcata (Vahl) Kunth & Fimbristylis & Whole plants & 16.30 & Rajakaruna and Bohm, 2002 \\
\hline Dennstaedtiaceae & Lindsaea gueriniana (Gaudich.) Desv. & Goldenbush & Leaves & 5.00 & Van der Ent and Reeves, 2015 \\
\hline Dennstaedtiaceae & Tapeinidium acuminatum K.U. Kramer & Tapeinidium ferns & Leaves & 22.00 & Van der Ent and Reeves, 2015 \\
\hline Droseraceae & Drosera montana A.St.-Hil. & Sundews & Leaves & 34.00 & Van der Ent and Reeves, 2015 \\
\hline Ebenaceae & Diospyros lanceifolia Roxb. & Common Malayan ebony & Leaves & 2.00 & Van der Ent and Reeves, 2015 \\
\hline Equisetaceae & Equisetum arvense L. & Bottlebrush & Shoots & 0.80 & Koleli et al., 2015 \\
\hline Ericaceae & Empetrum nigrum L. & Crow-berry & Leaves & 0.05 & Reimann et al., 2001 \\
\hline Ericaceae & Vaccinium myrtillus L. & Blue-berry & Leaves & 0.04 & Reimann et al., 2001 \\
\hline Ericaceae & Vaccinium vitis-idaea $\mathrm{L}$. & Cow-berry & Leaves & 0.04 & Reimann et al., 2001 \\
\hline
\end{tabular}


TABLE 3 | Continued

\begin{tabular}{|c|c|c|c|c|c|}
\hline Family & Species & Common name & Plant organ & Content (mg/kg) & References \\
\hline Euphorbiaceae & Croton bonplandianus Baill. & Bonpland's croton & $\begin{array}{l}\text { Stems, leaves and } \\
\text { flowers }\end{array}$ & 1.60 & Rajakaruna and Bohm, 2002 \\
\hline Euphorbiaceae & Croton griffithii Hook.f. & Griffith's spurge & Leaves & 10.00 & Van der Ent and Reeves, 2015 \\
\hline Euphorbiaceae & Drypetes caesia Airy Shaw & Drypetes & Leaves & 2.00 & Van der Ent and Reeves, 2015 \\
\hline Euphorbiaceae & Euphorbia macrostegia Boiss. & Persian wood spurge & Shoots & 0.90 & Koleli et al., 2015 \\
\hline Euphorbiaceae & Euphorbia rubicunda Blume & Chicken weed & $\begin{array}{l}\text { Stems, leaves and } \\
\text { flowers }\end{array}$ & 1.30 & Rajakaruna and Bohm, 2002 \\
\hline Euphorbiaceae & $\begin{array}{l}\text { Euphorbia selloi (Klotzsch and Garcke) } \\
\text { Boiss. }\end{array}$ & Spurge & Leaves & 72.00 & Van der Ent and Reeves, 2015 \\
\hline Euphorbiaceae & Phyllanthus sp. & Leaf-flower & Leaves & 85.00 & Van der Ent and Reeves, 2015 \\
\hline Fabaceae & Mimosa pudica L. & Mimosa plant & Leaves & 0.04 & Van Tran and Teherani, 1989 \\
\hline Fabaceae & Dalbergia beccarii Prain & Beccari's dalbergia & Leaves & 4.00 & Van der Ent and Reeves, 2015 \\
\hline Iridaceae & Gladiolus italicus Miller & Field gladiolus & Shoots & 1.50 & Koleli et al., 2015 \\
\hline Iridaceae & Sisyrinchium luzula Klotzsch ex Klatt & Blue-eyed grass & Leaves & 11.00 & Van der Ent and Reeves, 2015 \\
\hline Labiatae & Mentha piperita L. & Mint & Shoots & $0.04-0.17$ & Ciotea et al., 2021 \\
\hline Labiatae & Ocimum basilicum L. & Basil & Shoots & $0.11-0.16$ & Ciotea et al., 2021 \\
\hline Labiatae & Rosmarinus officinalis L. & Rosemary & Shoots & $0.07-0.14$ & Ciotea et al., 2021 \\
\hline Lamiaceae & Clerodendrum infortunatum L. & Hill glory bower & $\begin{array}{l}\text { Stems, leaves and } \\
\text { flowers }\end{array}$ & 0.60 & Rajakaruna and Bohm, 2002 \\
\hline Lamiaceae & Crotalaria biflora L. & Two-flower rattlebox & $\begin{array}{l}\text { Stems, leaves and } \\
\text { flowers }\end{array}$ & 15.90 & Rajakaruna and Bohm, 2002 \\
\hline Lamiaceae & Geniosporum tenuiflorum (L.) Merr. & Holy basil & Whole plants & 10.80 & Rajakaruna and Bohm, 2002 \\
\hline Lamiaceae & Leucas zeylanica (L.) R.Br. & Ceylon leucas & Whole plants & 3.30 & Rajakaruna and Bohm, 2002 \\
\hline Lamiaceae & Leucas zeylanica (L.) R.Br. & Ceylon leucas & Whole plants & 9.40 & Rajakaruna and Bohm, 2002 \\
\hline Lamiaceae & Ajuga reptans L. & Bugleweed & Shoots & 0.90 & Koleli et al., 2015 \\
\hline Lamiaceae & $\begin{array}{l}\text { Haumaniastrum katangense (S. Moore) } \\
\text { Duvign. Plancke }\end{array}$ & Copper flower & Leaves & 260.00 & Morrison, 1979 \\
\hline Lamiaceae & Sideritis trojana Bornm. & Sideritis & Shoots & 0.90 & Koleli et al., 2015 \\
\hline Lamiaceae & Thymus pulvinatus Celak & Common thyme & Shoots & 0.20 & Koleli et al., 2015 \\
\hline Lamiaceae & $\begin{array}{l}\text { Hypenia macrantha (A.St.-Hil. ex Benth.) } \\
\text { Harley }\end{array}$ & Hypenia & Leaves & 10.00 & Van der Ent and Reeves, 2015 \\
\hline Lamiaceae & Lippia aff. geminata & Lippia & Leaves & 11.00 & Van der Ent and Reeves, 2015 \\
\hline Lamiaceae & Lippia sp. & Lippia & Leaves & 14.00 & Van der Ent and Reeves, 2015 \\
\hline Leguminoseae & Tephrosia purpurea (L.) Pers. & Wild indigo & $\begin{array}{l}\text { Stems, leaves and } \\
\text { flowers }\end{array}$ & 5.20 & Rajakaruna and Bohm, 2002 \\
\hline Leguminoseae & Baptisia australis (L.) R. Br. ex Ait. f. & Blue false indigo & Shoots & 0.50 & Koleli et al., 2015 \\
\hline Leguminoseae & Vicia cassubica L. & Vicia & Shoots & 5.50 & Koleli et al., 2015 \\
\hline Liliaceae & Allium cepa L. & Onion & Shoots & 3.50 & Koleli et al., 2015 \\
\hline Liliaceae & Asphodelus aestivus Brot. & Summer asphodel & Shoots & 0.80 & Koleli et al., 2015 \\
\hline Loganiaceae & Norrisia sp. 1 & Norrisia & Leaves & 8.00 & Van der Ent and Reeves, 2015 \\
\hline Malvaceae & Abutilon indicum (L.) Sweet & Abutilon & $\begin{array}{l}\text { Stems, leaves and } \\
\text { flowers }\end{array}$ & 0.80 & Rajakaruna and Bohm, 2002 \\
\hline Malvaceae & Hibiscus rhodanthus Gürke ex Schinz & Dwarf red hibiscus & Leaves & $21.00-1,971.00$ & Faucon et al., 2007 \\
\hline Malvaceae & Sida acuta Burm.f & Wire weed & Whole plants & 0.30 & Rajakaruna and Bohm, 2002 \\
\hline Malvaceae & Waltheria indica L. & Sleepy morning & Whole plants & 1.33 & Rajakaruna and Bohm, 2002 \\
\hline Melastomataceae & Pterolepis sp. nov. & Pterolepis & Leaves & 11.00 & Van der Ent and Reeves, 2015 \\
\hline Myrtaceae & Syzygium cf. pterophera & Syzygium & Leaves & 7.00 & Van der Ent and Reeves, 2015 \\
\hline Myrtaceae & $\begin{array}{l}\text { Syzygium clavatum (Korth.) Merr. and } \\
\text { L.M.Perry }\end{array}$ & Syzygium & Leaves & 3.00 & Van der Ent and Reeves, 2015 \\
\hline Phyllanthaceae & Actephila sp. nov. & Actephila & Leaves & 65.00 & Van der Ent et al., 2015 \\
\hline Phyllanthaceae & Antidesma coriaceum Tul. & Antidesma & Leaves & 2.00 & Van der Ent et al., 2015 \\
\hline Phyllanthaceae & Aporosa benthamiana Hook.f. & Aporosa & Leaves & 6.00 & Van der Ent et al., 2015 \\
\hline Phyllanthaceae & Aporosa falcifera Hook.f. & Aporosa & Leaves & 18.00 & Van der Ent et al., 2015 \\
\hline
\end{tabular}


TABLE 3 | Continued

\begin{tabular}{|c|c|c|c|c|c|}
\hline Family & Species & Common name & Plant organ & Content (mg/kg) & References \\
\hline Phyllanthaceae & Aporosa lucida (Miq.) Airy Shaw & Aporosa & Leaves & 18.00 & Van der Ent et al., 2015 \\
\hline Phyllanthaceae & Baccaurea lanceolata (Miq.) Müll.Arg. & Baccaurea & Leaves & 179.00 & Van der Ent et al., 2015 \\
\hline Phyllanthaceae & Breynia coronata Hook.f. & Breynia & Leaves & 4.00 & Van der Ent et al., 2015 \\
\hline Phyllanthaceae & Cleistanthus ellipticus Hook.f. & Cleistanthus & Leaves & 6.00 & Van der Ent et al., 2015 \\
\hline Phyllanthaceae & Cleistanthus gracilis Hook.f. & Cleistanthus & Leaves & 10 & Van der Ent et al., 2015 \\
\hline Phyllanthaceae & Cleistanthus myrianthus (Hassk.) Kurz & Cleistanthus & Leaves & 2.00 & Van der Ent et al., 2015 \\
\hline Phyllanthaceae & Cleistanthus gracilis Hook.f. & Cleistanthus & Leaves & 189.00 & Van der Ent and Reeves, 2015 \\
\hline Phyllanthaceae & Glochidion angulatum C.B.Rob. & Glochidion & Leaves & 23.00 & Van der Ent et al., 2015 \\
\hline Phyllanthaceae & Glochidion arborescens Blume & Glochidion & Leaves & 272.00 & Van der Ent et al., 2015 \\
\hline Phyllanthaceae & Glochidion borneense (Müll.Arg.) Boerl. & Glochidion & Leaves & 21.00 & Van der Ent et al., 2015 \\
\hline Phyllanthaceae & Glochidion brunneum Hook.f. & Glochidion & Leaves & 38.00 & Van der Ent et al., 2015 \\
\hline Phyllanthaceae & Glochidion calospermum Airy Shaw & Glochidion & Leaves & 13.00 & Van der Ent et al., 2015 \\
\hline Phyllanthaceae & Glochidion cf. lanceisepalum & Glochidion & Leaves & 9.00 & Van der Ent and Reeves, 2015 \\
\hline Phyllanthaceae & Glochidion lanceilimbum Merr. & Glochidion & Leaves & 13.00 & Van der Ent et al., 2015 \\
\hline Phyllanthaceae & Glochidion littorale Blume & Glochidion & Leaves & 8.00 & Van der Ent et al., 2015 \\
\hline Phyllanthaceae & Glochidi on lutescens Blume & Glochidion & Leaves & 2.00 & Van der Ent et al., 2015 \\
\hline Phyllanthaceae & Glochidion mindorense C.B.Rob. & Glochidion & Leaves & 16.00 & Van der Ent and Reeves, 2015 \\
\hline Phyllanthaceae & Glochidion monostylum Airy Shaw & Glochidion & Leaves & 5.00 & Van der Ent et al., 2015 \\
\hline Phyllanthaceae & Glochidion rubrum Blume & Glochidion & Leaves & 14.00 & Van der Ent et al., 2015 \\
\hline Phyllanthaceae & Glochidion rubrum Blume & Glochidion & Leaves & 25.00 & Van der Ent and Reeves, 2015 \\
\hline Phyllanthaceae & Glochidion singaporense Gage & Glochidion & Leaves & 120.00 & Van der Ent et al., 2015 \\
\hline Phyllanthaceae & $\begin{array}{l}\text { Glochidionobscurum (Roxb. ex Willd.) } \\
\text { Blume }\end{array}$ & Glochidion & Leaves & 8.00 & Van der Ent et al., 2015 \\
\hline Phyllanthaceae & Glochidionsuperbum Baill. ex Müll.Arg. & Great-leafed pin-flower Tree & Leaves & 22.00 & Van der Ent et al., 2015 \\
\hline Phyllanthaceae & $\begin{array}{l}\text { Phyllanthus amarus Schumach. and } \\
\text { Thonn. }\end{array}$ & Sleeping plan & Leaves & 38.00 & Van der Ent et al., 2015 \\
\hline Phyllanthaceae & $\begin{array}{l}\text { Phyllanthus balgooyi Petra Hoffm. and } \\
\text { A.J.M.Baker }\end{array}$ & Phyllanthus & Leaves & 26.00 & Van der Ent et al., 2015 \\
\hline Phyllanthaceae & $\begin{array}{l}\text { Phyllanthus balgooyi Petra Hoffm. and } \\
\text { A.J.M.Baker }\end{array}$ & Phyllanthus & Leaves & 11.00 & Van der Ent and Reeves, 2015 \\
\hline Phyllanthaceae & Phyllanthus kinabaluicus Airy Shaw & Phyllanthus & Leaves & 109.00 & Van der Ent et al., 2015 \\
\hline Phyllanthaceae & Phyllanthus lamprophyllus Müll.Arg. & Phyllanthus & Leaves & 11.00 & Van der Ent et al., 2015 \\
\hline Phyllanthaceae & Phyllanthus myrtifolius (Wight) Müll.Arg. & Mousetail plant & $\begin{array}{l}\text { Stems, leaves and } \\
\text { flowers }\end{array}$ & 0.50 & Van der Ent et al., 2015 \\
\hline Phyllanthaceae & Phyllanthus pulcher Wall. ex Müll.Arg. & Tropical leaf-flower & Leaves & 31.00 & Van der Ent et al., 2015 \\
\hline Phyllanthaceae & Phyllanthus reticulatus Poir. & Black-honey shrub & Leaves & 5.00 & Van der Ent et al., 2015 \\
\hline Phyllanthaceae & Phyllanthus sp. & Leaf-flower & $\begin{array}{l}\text { Stems, leaves and } \\
\text { flowers }\end{array}$ & 2.40 & Van der Ent et al., 2015 \\
\hline Phyllanthaceae & Phyllanthus sp. nov. "serinsim" & Phyllanthus & Leaves & 158.00 & Van der Ent et al., 2015 \\
\hline Phyllanthaceae & Phyllanthus urinaria L. & Chamber bitter & Leaves & 12.00 & Van der Ent et al., 2015 \\
\hline Pinaceae & Picea abies (L.) H.Karst. & Spruce & Needles & 0.07 & Reimann et al., 2001 \\
\hline Pinaceae & Pinus sylvestris L. & Pine & Needles & 0.07 & Reimann et al., 2001 \\
\hline Piperaceae & Piper officinarum C.DC. & Piper & Leaves & 13.00 & Van der Ent and Reeves, 2015 \\
\hline Poaceae & $\begin{array}{l}\text { Cymbopogan flexuosus (Nees ex Steud.) } \\
\text { Will.Watson }\end{array}$ & Lemongrass & Whole plants & 0.30 & Rajakaruna and Bohm, 2002 \\
\hline Poaceae & Imperata cylindrica (L.) Raeusch. & Alang grass & Leaves & 0.03 & Van Tran and Teherani, 1989 \\
\hline Poaceae & Oryza sativa L. & Rice & Seeds & 0.04 & Van Tran and Teherani, 1989 \\
\hline Poaceae & Hordeum murinum L. & Mouse Barley & Shoots & 0.80 & Koleli et al., 2015 \\
\hline Poaceae & Aristida setacea Retz. & Broom grass & Whole plants & 14.60 & Rajakaruna and Bohm, 2002 \\
\hline Polygonaceae & Rumex obtusifolius L. & Bitter dock & Shoots & 0.80 & Koleli et al., 2015 \\
\hline Rubiaceae & Agrostemma cf. hameliifolium & Corncockle & Leaves & 16.00 & Van der Ent and Reeves, 2015 \\
\hline
\end{tabular}


TABLE 3 | Continued

\begin{tabular}{|c|c|c|c|c|c|}
\hline Family & Species & Common name & Plant organ & Content (mg/kg) & References \\
\hline Rubiaceae & Canthium puberulum Thwaites ex Hook.f. & Canthium & $\begin{array}{l}\text { Stems, leaves and } \\
\text { flowers }\end{array}$ & 0.12 & Rajakaruna and Bohm, 2002 \\
\hline Rubiaceae & Canthium sp. & Kidney-fruit Canthium & $\begin{array}{l}\text { Stems, leaves and } \\
\text { flowers }\end{array}$ & 5.10 & Rajakaruna and Bohm, 2002 \\
\hline Rubiaceae & Morinda tinctoria Roxb & Noni & $\begin{array}{l}\text { Stems, leaves and } \\
\text { flowers }\end{array}$ & 0.70 & Rajakaruna and Bohm, 2002 \\
\hline Rubiaceae & Tarenna asiatica (L.) Kuntze ex K.Schum & Tharana & $\begin{array}{l}\text { Stems, leaves and } \\
\text { flowers }\end{array}$ & 1.10 & Rajakaruna and Bohm, 2002 \\
\hline Rubiaceae & Urophyllum cf. macrophyllum & Urophyllum & Leaves & 1.00 & Van der Ent and Reeves, 2015 \\
\hline Salicaceae & Salix spp. & Willow & Leaves & 1.76 & Reimann et al., 2001 \\
\hline Solanaceae & Physalis minima L. & Cut-leaved ground-Cherry & $\begin{array}{l}\text { Stems, leaves and } \\
\text { flowers }\end{array}$ & 3.90 & Rajakaruna and Bohm, 2002 \\
\hline Taxodiaceae & Taxodium distichum (L.) Rich. & Bald cypress & leaves & 4.60 & McLeod and Ciravolo, 2007 \\
\hline Turneraceae & Piriqueta duarteana Urb. & Stripeseed & Leaves & 11.00 & Van der Ent and Reeves, 2015 \\
\hline Turneraceae & Piriqueta sp. & Stripeseed & Leaves & 149.00 & Van der Ent and Reeves, 2015 \\
\hline Turneraceae & $\begin{array}{l}\text { Turnera melochioides A.St.-Hil. and } \\
\text { Cambess. }\end{array}$ & Turnera & Leaves & 143.00 & Van der Ent and Reeves, 2015 \\
\hline Umbelliferae & Conium maculatum L. & Poison hemlock & Shoots & 1.10 & Koleli et al., 2015 \\
\hline Umbelliferae & Sanicula europaea L. & Sanicle, Wood sanicle & Shoots & 5.40 & Koleli et al., 2015 \\
\hline Violaceae & Hybanthus enneaspermus F.Muell. & Blue spade flower & Whole plants & 17.00 & Rajakaruna and Bohm, 2002 \\
\hline
\end{tabular}

\section{Plant Growth Improvement}

Cobalt at low concentrations can also promote the growth of non-leguminous crops (Table 4). Co applied to a sandy soil at $1 \mathrm{mg} / \mathrm{kg}$ enhanced shoot and root dry weights of wheat by 33.7 and $35.8 \%$, respectively compared with the control (Aery and Jagetiy, 2000), and the same Co rate applied to a sandy loam soil increased shoot and root dry weights of wheat by 27.9 and $39.6 \%$, respectively, compared with the control. The yield and essential oil contents of parsley (Petroselinum crispum) increased considerably after the application of Co at $25 \mathrm{mg} / \mathrm{kg}$ soil (Helmy and Gad, 2002). Plant height, branch numbers, and fruit numbers as well as anthocyanin and flavonoids contents of Hibiscus sabdariffa significantly increased after application of Co at 20 and $40 \mathrm{mg} / \mathrm{kg}$ (Aziz et al., 2007). Application of 50, $100,150,200$, and $250 \mathrm{mg} / \mathrm{kg}$ Co to corn plants showed that the root length, shoot height, and the number of cobs and seeds per plant increased when plants were applied with $50 \mathrm{mg} / \mathrm{kg} \mathrm{Co}$, but these parameters decreased with $100 \mathrm{mg} / \mathrm{kg}$ Co and above (Jaleel et al., 2009). Co applied at $10 \mathrm{mg} / \mathrm{kg}$ significantly enhanced the growth of two onion cultivars, bulb yields, bulb length, and bulb quality, such as nutrient and essential oil contents. Bulb diameter and bulb weights were much higher than the control treatment (Attia et al., 2014), but Co concentrations higher than $10 \mathrm{mg} / \mathrm{kg}$ significantly reduced the promotive effects.

Explanations for the improved growth of non-leguminous plants vary but can be summarized as follows: (1) enhanced tolerance to abiotic stresses, (2) activation of antioxidative enzymes, (3) substitution of active metals, and (4) hormesis. Application of Co has been reported to alleviate drought, salt, heavy metal stresses, thus plant growth is not adversely affected. Co has been reported to suppress plant uptake of cadmium (Chmielowska-Bak et al., 2014). Co application increased free proline accumulation, which counteracted the salt stress. In general, abiotic stresses often cause plant imbalance between production and accumulation of reactive oxygen species (ROS), including superoxide anion $\left(\mathrm{O}_{2}^{-}\right)$, hydroxyl radical $\left(\mathrm{OH}^{-}\right)$, and hydrogen peroxide $\left(\mathrm{H}_{2} \mathrm{O}_{2}\right)$ (Sachdev et al., 2021). ROS can activate the antioxidant system of the plant, thus minimizing the damages (Tewari et al., 2002; Choudhury et al., 2017). The antioxidant system includes enzymatic antioxidants: ascorbate peroxidase, catalase, dehydroascorbate reductase, general peroxidases, glutathione reductase, monodehydroascorbate reductase, and superoxide dismutase as well as non-enzymatic antioxidants, mainly ascorbic acid, $\alpha$-tocopherol, carotenoids, reduced glutathione, plastoquinone/ubiquinone, and flavonoids (García-Caparrós et al., 2020). The action of the antioxidant system could be the first line of defense against the adverse effects. Therefore, it is not surprising to notice increased activities of ascorbate peroxidase, catalase, peroxidase, and superoxide dismutase (Hasanuzzaman et al., 2020). Co applied at appropriate concentrations can activate antioxidative enzymes, thus reducing ROS-caused damage. As discussed previously, Co may substitute other nutrient elements when such nutrients have limited availability. Baxter et al. (2008) showed that when Arabidopsis plants are grown under a low Fe concentration, the shoot concentration of Co increased, which was concomitant with the increased expression of Fe transporter IRT1. Additionally, Co contribution to hormesis has been proposed (Shahid et al., 2020). Due to the limited research on Co to date, these explanations may not be on target and incomplete. Our proposition is that the application of the appropriate amount of Co may stimulate rhizosphere bacteria (either symbiotic, endophytic, or associated ones) to fix $\mathrm{N}_{2}$, increase soil $\mathrm{N}$, and enhance plant growth. Concomitantly, 
TABLE 4 | Effects of cobalt application on plant performance.

\begin{tabular}{|c|c|}
\hline Species (common name) & Co application \\
\hline $\begin{array}{l}\text { Actinidia chinensis Planch. cv. } \\
\text { Hayward) (Kiwi) }\end{array}$ & Fruit was treated with $1 \mathrm{mM} \mathrm{Co}^{2+}$ solution \\
\hline $\begin{array}{l}\text { Adiantum raddianum C. Presl } \\
\text { (Delta maidenhair fern) }\end{array}$ & $\begin{array}{l}\text { Cut green (frond) was treated with } 1 \mathrm{mM} \\
\mathrm{Co}\left(\mathrm{NO}_{3}\right)_{2} \text { solution }\end{array}$ \\
\hline Arachis hypogaea L. (Peanut) & $\begin{array}{l}\text { Seeds were treated with } \mathrm{Co}\left(\mathrm{NO}_{3}\right)_{2} \text { at } 500 \\
\mathrm{mg} / \mathrm{kg} \text { seed and followed by two foliar } \\
\text { sprays of cobalt nitrate at } 500 \mathrm{mg} / \mathrm{L} \text { before } \\
\text { and after flowering }\end{array}$ \\
\hline
\end{tabular}

Arachis hypogaea L. (Peanut)

Arachis hypogaea L. (Peanut)

Argyranthemum sp.

(Argyranthemum)

Avena sativa L. var. 'Condor'

(Common oat)

Beta vulgaris L. (Red beet)

Cajanus cajan (L.) Millsp. (Pigeon pea)

Cariandrum sativum L. (Coriander)

Cicer arietinum L. cv GG2

(Chickpea)

Cucumis sativus L. CV.

(Cucumber)

Cucurbita pepo cv. Eskandarany (summer squash)

\author{
Allium cepa L.) cv. Giza 6 \\ Mohassan (Onion) \\ Dianthus caryophyllus L. CV. \\ "Harlem" (Carnation) \\ Gladiolus grandiflorus Hort. cv. \\ Borrega Roja (Gladiolus)
}

Glycine max (L.) Merr. (Soybean)

Glycine max (L.) Merr. (Soybean)

Glycine max (L.) Merr. (Soybean)

Seeds were treated with $0.001 \% \mathrm{CoSO}_{4}$ solution for $24 \mathrm{~h}$, dried at room temperature for 3 days, then sown $\mathrm{CoSO}_{4}$ was mixed with soil at 2.5, 5.0, $7.5,10.0$ and $12.5 \mathrm{mg} / \mathrm{kg}$, respectively

Seeds were treated with $\mathrm{Co}\left(\mathrm{NO}_{3}\right)_{2}$ at 500 $\mathrm{mg} / \mathrm{kg}$ seed

Irrigated in the form of $\mathrm{CoSO}_{4} 12.5 \mathrm{mg} / \mathrm{L}$ once

Chickpea seedlings at the three-leaf stage were fertigated with $\mathrm{CoCl}_{2}$ at $100 \mathrm{~g} / \mathrm{ha}$ Plants were treated with $\mathrm{Co}\left(\mathrm{NO}_{3}\right)_{2}$ solutions ranging from 1 to 500 ?M Seeds in continuously aerated solutions of $0.25,0.50$, and $1.00 \mathrm{mg} / \mathrm{L} \mathrm{Co}^{2+}$ for $48 \mathrm{~h}$ before sowing

Co mixed with sand and petmoss in 10.0 $\mathrm{mg} / \mathrm{kg}$ soil

Cut flowers were preserved in $\mathrm{CoCl}_{2}$ solutions at 50,75 , and $100 \mathrm{mg} / \mathrm{L}$, respectively

Plants were treated with solution containing $0.3 \mathrm{mM} \mathrm{CoCl}_{2}$

Plants were grown in nutrient solutions containing 1 and $5 \mu \mathrm{g} / \mathrm{L}$ cobaltous chloride, inoculated with rhizobia in the absence of nitrogen

Plants were grown in soil mixed with finely powdered $\left(\mathrm{CoCl}_{2}\right)$ at the concentration of $50 \mathrm{mg} / \mathrm{kg}$

Seeds were sown in soil mixed with finely powdered $\left(\mathrm{CoCl}_{2}\right)$ at $50 \mathrm{mg} / \mathrm{kg}$

Significantly promote nutrients and essential

Increased root and shoot length, leaf area, dry
Effects on plants

Inhibited ACC activity in ethylene biosynthesis

Prolonged vase life of frond from 3 to 8.2 days

Significantly increased plant height, leaf number, pod yield, shelling percentage, harvest index, and total dry matter

Resulted in 10\% higher kernel yield compared with control (without Co application)

Increased plant height, number of branches and leaf number, leaf area index, root length, shoot and root biomass as well as pods numbers, pods weight, oil yield, total proteins, total carbohydrates, total soluble sugars, and total soluble solids

Increased flower longevity by more than 5 days compared with control (treated with distilled water)

Increased grain yields

\section{References}

Hyodo and Fukasawa, 1985

Fujino and Reid, 1983

Raj, 1987

Basu and Bhadoria, 2008

Gad, 2012a

Kazemi, 2012

Saric and Saciragic, 1969

Increased plant growth, root yield, mineral elements as well as protein, carbohydrate, vitamin C, sucrose, and glucose contents Increased chlorophyll content, crop growth rate, relative growth rate, and net assimilation rate, resulting in increased plant height, number of branches, leaves, total dry matter, and yield

Increased coriander herb yield, mineral composition (except Fe), chemical constituents as well as essential oil components

Increased protein content and yield by 5.08 and $22.36 \%$, respectively

Promoted hypocotyl elongation

Strongly increased plant growth, femaleness, and fruit yield compared with those of water(control) or 0.5 mM AOA (aminooxyacetic acid)-soaked seed oils content along with bulb length, bulb diameter and weight

Suppressed ethylene production and prolonged vase life

Increased stem and leaf N content, chlorophyll concentrations, leaf and stem dry weights, and improved stem absorption of water

No $\mathrm{N}$ deficiency symptoms, and increased dry weight by $52 \%$ compared with the control treatments weight, yield, and yield components

Increased yield parameters, leaf area, shoot length, total dry weight as well as total phenol percentage
Gad and Kandil, 2009

Raj, 1987

Gad, 2012b

Rod et al., 2019

Grover and Purves, 1976

Atta-Aly, 1998

Attia et al., 2014

Jamali and Rahemi, 2011

Trejo-Téllez et al., 2014

Ahmed and Evans, 1959

Jayakumar et al., 2009

Vijayarengan et al., 2009 
TABLE 4 | Continued

\begin{tabular}{|c|c|}
\hline Species (common name) & Co application \\
\hline $\begin{array}{l}\text { Hevea brasiliensis (Willd. ex } \\
\text { A.Juss.) Müll.Arg. (Rubber) }\end{array}$ & $\begin{array}{l}\text { Plants were grown in Co free sand } \\
\text { supplemented with } 0.005 \text { mg/kg Co }\end{array}$ \\
\hline Hibiscus sabdariffa L. (Roselle) & $\begin{array}{l}\text { Seedlings irrigated once with Co at } \\
\text { concentrations of } 20 \text { and } 40 \mathrm{mg} / \mathrm{L}\end{array}$ \\
\hline $\begin{array}{l}\text { Ipomoea batatas L. (Sweet } \\
\text { potato) }\end{array}$ & $\begin{array}{l}\text { Seedlings were irrigated with } \mathrm{CoSO}_{4} \text { once } \\
\text { at concentrations of } 5.0,7.5,10.0 \mathrm{mg} / \mathrm{L}\end{array}$ \\
\hline Lilium spp. cv. Star Gazer Lily & $\begin{array}{l}\text { Cut flowers were preserved in a solution } \\
\text { containing } 0.1 \mathrm{mM} \text { Co and } 4 \% \text { sucrose } \\
\text { with a pH of } 3.5\end{array}$ \\
\hline Lilium spp. cv. Prato (Lily) & Cut flowers were treated with $2 \mathrm{mM} \mathrm{CoCl}_{2}$ \\
\hline Lilium spp. cv. Star Fighter (Lily) & $\begin{array}{l}\text { Cut flowers were preserved in solutions } \\
\text { containing } 0.1,0.2 \mathrm{mM} \text { Co and } 4 \% \\
\text { sucrose with a pH of } 3.5\end{array}$ \\
\hline $\begin{array}{l}\text { Lupinus angustifolius cv. } \\
\text { Uniharvest (Blue lupin) }\end{array}$ & $\begin{array}{l}\text { Supplemented } 0.9 \mathrm{mg} \mathrm{CoSO} \\
\text { each pot containing } 6 \mathrm{~kg} \text { soil }\end{array}$ \\
\hline $\begin{array}{l}\text { Lycopersicon esculantum Mill. } \\
\text { (Tomato) }\end{array}$ & $\begin{array}{l}\text { Ten seeds were sown in a pot containing } \\
3 \mathrm{~kg} \text { air-dried soil mixed with } \mathrm{CoCl}_{2} \text { at } 50 \\
\mathrm{mg} / \mathrm{kg} \text {, seedlings were thinned to } 3\end{array}$ \\
\hline $\begin{array}{l}\text { Lycopersicon esculentum Mill. } \\
\text { (Tomato) }\end{array}$ & $\begin{array}{l}\text { Treated with simple solutions }(1 \mathrm{mM} \\
\mathrm{CoCl}_{2} \text { ) plus wetting agent }\end{array}$ \\
\hline Malus domestica Borkh. (Apple) & $\begin{array}{l}\text { Apple fruit was immersed in a solution } \\
\text { containing } 1 \mathrm{mM} \mathrm{CoCl}_{2} \text { for } 1 \mathrm{~min}\end{array}$ \\
\hline
\end{tabular}

Mangifera indica L) cv. Langra (Mango)

\section{Matteuccia struthiopteris (L.) \\ Todaro}

Phaseolus aureus Roxb. cv. T-44 (Mung bean)

Phaseolus vulgaris L. Cv. "Burpees Stringless" (Common bean)

Pisum sativum L. (Garden pea)

Pisum sativum L. (garden pea)

Polianthes tuberosa L. (Tuberose)

Pteridium aquilinum (L.) Kuhn var. latiusculum (Desv.) Underw. ex Heller (Western bracken fern) Ricinus communis L. (Castor bean)

Rosa hybrida "Samantha" (Rose)

Rosa hybrida "Samantha" (Rose)

Rosa spp.cv. Red one (Rose)
Foliar spray with $\mathrm{CoSO}_{4}$ at 1,000 mg/L prior to flower bud differentiation in the first week of October

Supplemented with various concentrations $\mathrm{Co}^{2+}$ ranging from 0.1 to $1 \mathrm{mM}$

Plants were treated with $50 \mu \mathrm{M}$ Co in sand culture

Two cycles of pre-sowing soaking and drying treatments by a $1 \mathrm{mg} / \mathrm{L}$ of $\mathrm{Co}\left(\mathrm{NO}_{3}\right)_{2}$ solution

Seeds sowed in pot containing $10 \mathrm{~kg}$ soil mixed with $\mathrm{CoSO}_{4}$ at $8 \mathrm{mg} / \mathrm{kg}$

Pots filled with $10 \mathrm{~kg}$ soil with Co at 2 $\mathrm{mg} / \mathrm{kg}$

Flower stems were preserved in a solution containing 300 mg/L cobalt chloride Stems of cut green were preserved in solutions containing 0.1 to $1.0 \mathrm{mM}$ Co

Plants treated with a $1 \mathrm{mM} \mathrm{CoCl} \mathrm{Cl}_{2}$ solution supplemented with a wetting agent

Cut flowers were preserved in solutions containing $0.5,1.0,1.5$, and $2.0 \mathrm{mM}$ $\mathrm{CoCl}_{2}$, respectively

Cut flowers were preserved in solutions containing $0.5,1.0,1.5$, and $2.0 \mathrm{mM}$ $\mathrm{Co}\left(\mathrm{NO}_{3}\right)_{2}$, respectively

Cut flowers treated with 100 and 200 $\mathrm{mg} / \mathrm{L}$ Co solutions
Effects on plants

Increased plant height, stem diameter, and plant dry weight

Increased plant height, branch numbers, and fruit numbers as well as anthocyanin and flavonoids contents

Increased growth and yield parameters, nutrient elements (except for $\mathrm{Fe}$ ) and the chemical contents

Extended vase life

Increased vase life from seven to 9 days

Extended the lifespan of flowers

Increased plant growth and $\mathrm{N}$ content

Increased the content of phosphorus, potassium, copper, iron, manganese, and zinc in plants

Delayed gravitropic responses of treated plants

Enhanced activity of protein inhibitor of polygalacturonase (PIPG) and provided better conservation of apple fruit consistency during storage

Reduced floral malformation by $65 \%$ and increased the fruit yield by $35 \%$

Inhibited IAA-induced ethylene production in sporophytes

Improved plant growth by increasing leaf, stem, and total dry weight compared with the controls Increased yield and $\mathrm{N}$ content over untreated and distilled water-soaked seeds by 48 and $150 \%$, respectively

Enhanced $\mathrm{N}_{2}$ fixation process, increased plant $\mathrm{N}$ content, and reduced inorganic and organic $\mathrm{N}$ fertilizer application by 75 and $33.3 \%$, respectively

Increased grain yield by $48.4 \%$

Extended the vase life and enhanced water uptake in cut tuberose flowers

Inhibited IAA-induced ethylene production and prolonged vase life

Delayed gravitropic responses of treated plants

Increased leaf diffusive resistance, inhibited xylem blockage, maintained water flow and uptake, and increased the vase life

Highly delayed or prevented the development of bent-neck and increased water uptake of cut flower

Inhibited vascular blockage in the stem of rose and maintained a high-water flow rate, leading to significantly water uptake by cut flowers

\section{References}

Bolle-Jones and Mallikarjuneswara, 1957

Aziz et al., 2007

Gad and Kandil, 2008

Mandujano-Piña et al., 2012

Kazemi and Ameri, 2012

Mandujano-Piña et al., 2012

Robson et al., 1979

Jayakumar et al., 2013

Wheeler and Salisbury, 1981

Bulantseva et al., 2001

Singh et al., 1994

Tittle, 1987

Tewari et al., 2002

Mohandas, 1985

Gad, 2006

Singh et al., 2012

Mehrafarin et al., 2021

Tittle, 1987

Wheeler and Salisbury, 1981

Reddy, 1988

Murr et al., 1979

Aslmoshtaghi, 2014 
TABLE 4 | Continued

\begin{tabular}{|c|c|c|c|}
\hline Species (common name) & Co application & Effects on plants & References \\
\hline Triticum aestivum L. (Wheat) & $\begin{array}{l}\text { Seeds were sowed in polythene-lined pots } \\
\text { containing } 4 \mathrm{~kg} \text { of soil mixed with } 1 \mathrm{mg} / \mathrm{kg} \\
\mathrm{CoSO}_{4}\end{array}$ & $\begin{array}{l}\text { Enhanced plant growth after } 45 \text { days of } \\
\text { application }\end{array}$ & Aery and Jagetiy, 2000 \\
\hline Vicia faba L. (Fava bean) & $\begin{array}{l}\text { Seedlings at six-leaf stage were planted in } \\
\text { pot containing soil mixed cobalt at } 20 \text { and } \\
40 \mathrm{mg} / \mathrm{kg} \text {, respectively }\end{array}$ & Improved photosynthesis and plant growth & Wang et al., 2015 \\
\hline $\begin{array}{l}\text { Vigna anguiculata subsp. alba } \\
\text { (G. Don) Pasquet (Cowpea) }\end{array}$ & $\begin{array}{l}\text { Seedlings were applied with Co at } 4,6 \text {, } \\
\text { and } 8 \mathrm{mg} / \mathrm{kg}\end{array}$ & $\begin{array}{l}\text { Enhanced plant growth and yield and induced } \\
\text { nodulation }\end{array}$ & Gad and Hassan, 2013 \\
\hline $\begin{array}{l}\text { Xanthium strumarium L. } \\
\text { (Cocklebur) }\end{array}$ & $\begin{array}{l}\text { Plants treated with a } 1 \mathrm{mM} \mathrm{CoCl} \text { solution } \\
\text { supplemented with a wetting agent }\end{array}$ & Delayed gravitropic responses of treated plants & Wheeler and Salisbury, 1981 \\
\hline Zea mays L. (Maize) & $\begin{array}{l}\text { Seeds sowed in pots containing } 13 \mathrm{~kg} \text { soil } \\
\text { mixed with Co at } 50 \mathrm{mg} / \mathrm{kg}\end{array}$ & $\begin{array}{l}\text { Increased seedling growth, photosynthetic } \\
\text { pigments, and leaf chlorophyll contents }\end{array}$ & Jaleel et al., 2009 \\
\hline
\end{tabular}

Co enzymes may be triggered to conduct proper biochemical and physiological activities, such as carbonate dehydratase may enhance photosynthesis and Co-peroxidase may activate the enzymatic antioxidant system. As a result, healthy growing plants would take up more nutrients from the soil and improve their growth and overall stress tolerance.

\section{Other Performance Enhancement}

Cobalt has been shown to have other beneficial effects on plants. Co as a component of preservative solutions can improve the postharvest quality of floriculture crops by prolonging the vase life of cut flowers. Cut fronds of Delta maidenhair fern (Adiantum raddianum) placed in deionized water became wilted in just 3 days because of the vascular blockage at the basal end of the petiole. The wilting, however, could be delayed for up to 8 days by adding $1 \mathrm{mM}$ Co as $\mathrm{Co}\left(\mathrm{NO}_{3}\right)_{2}$ to the water (Fujino and Reid, 1983). The delay of senescence is attributed to the antibacterial activity of Co (Van Doorn et al., 1991). Co addition to preservative solutions increased leaf diffusive resistance, reduced xylem blockage, sustained water flow and uptake, and prolonged vase life of cut flowers of Rosa hybrida "Samantha". Reddy (1988) suggested that partial closure of stomata by Co was responsible for reducing the water loss/water uptake ratio, and thereby maintaining a higher water potential in the cut roses. Co was also reported to slow the senescence process in harvested lettuce (Tosh et al., 1979). $\mathrm{Co}^{3+}$ has been reported to form Co-complexes, which have antiviral activities (Chang et al., 2010). In addition to antibacterial and antiviral activities, Co shows inhibitory activity to 1-aminocyclopropane1-carboxylic acid (ACC) oxidase. Ethylene is synthesized from amino acid methionine by two key enzymes, ACC synthase, and ACC oxidase. Co can block the conversion of ACC to ethylene by inhibiting ACC oxidase activity in the ethylene biosynthesis pathway (Lau and Yang, 1976; Serek et al., 2006), thus increasing the vase life of cut flowers.

\section{COBALT DEFICIENCY OCCURS IN PLANTS}

Cobalt deficiency does occur in plants. Its deficiency symptoms include leaf chlorosis and necrosis, growth retardation, and reduced crop yield, resembling N-deficiency in plants (Liu, 1998). Co deficient legumes have reduced plant size, smaller and paleyellow leaves, and smaller pods compared with non-deficiency plants. Root growth is also affected by exhibiting an overall reduction of root volume and root lengths. Nodule size and numbers are less abundant than the plants without Co deficiency. Co deficiency causes reduced synthesis of methionine, thus limiting protein synthesis and contributing to the smaller-sized bacteroids (Marschner, 2011). Sweet lupin is particularly sensitive to Co deficiency (Robson et al., 1979). In field-grown lupins, Co deficiency reduced bacteroid number per gram of nodule (Chatel et al., 1978) and affected nodule development and function at different levels (Dilworth et al., 1979). Co deficiency in legumes can be assessed by analysis of Co contents in shoots. In general, deficient symptom appears when shoot Co falls in a range from 0.04 (Ozanne et al., 1963) to $0.02 \mathrm{mg} / \mathrm{kg}$ based on dry weight (Robson et al., 1979). To correct Co deficiency in leguminous crops, application of Co in a range of 1.8 to $145.6 \mathrm{~g}$ per hectare was reported (Havlin et al., 2013).

Cobalt deficiency also occurs in non-leguminous plants. Co deficiency causes growth retardation in rubber trees and tomato plants (Wilson and Nicholas, 1967). Symptoms of Co deficiency in corn and wheat showed leaf chlorosis and reduced growth (Wilson and Nicholas, 1967). Low leaves may become necrotic, root systems are reduced with decreased number of $\mathrm{N}_{2}$ fixing bacteria. Grasses with low contents of Co can result in Co deficiency of sheep and cattle. For countries, like South Australia, Sierra Leone, Malta, New Zealand, and Finland, where soils have low Co contents (Sillanpaa and Jansson, 1992), application of Co could improve forage grass growth and enrich tissue Co content. Thus, the feeding of ruminants with healthy grass can reduce Co deficiency (Lee, 1951; Dewey et al., 1958). Due to low Co concentrations in plants, Co deficiency in grazing animals may occur, which can be corrected by mixing Co salts with fertilizers or sand carriers to broadcast it over grazed pastures.

\section{COBALT TOXICITY IN PLANTS}

Cobalt at high concentrations causes cytotoxicity and phytotoxicity in plants, which is similar to $\mathrm{Cu}, \mathrm{Ni}$, and 
Zn. Cytotoxicity is the inhibition of mitosis and damage of chromosomes, and disruption of the endoplasmic reticulum of root tip cells (Rauser, 1981; Smith and Carson, 1981; Akeel and Jahan, 2020). Phytotoxicity varies depending on plant species and the concentration of Co in plant organs. Leguminous plants generally exhibit chlorosis or pale-white color on young leaves, and tomatoes show either interveinal chlorosis or diffused chlorosis on young leaves (Akeel and Jahan, 2020).

Cobalt toxicity to plants is uncommon in natural soils, but it happens when plants grow in Co contaminated soils. Soil contamination by Co is mainly from mining and smelting activities, disposal of sewage sludge, and the use of chemical fertilizers (Hamilton, 1994). As discussed above, plants can control Co absorption, transport, and distribution. However, when Co in contaminated soils becomes highly available, Co may gain a competitive advantage over Fe, resulting in more Co being absorbed than Fe through IRT1. With increasing concentrations of Co inside cells, FPN2 may not be able to effectively sequester Co into the vacuole, resulting in more Co to transport from roots to shoots. Li et al. (2020) showed that Co concentrations in shoots of barley, oilseed rape (Brassica napus), and tomato were linearly correlated with the soil solution Co. As a result, excessive Co in shoots may initially cause oxidative stress, resulting in increased anti-oxidative enzyme activities (Tewari et al., 2002). As the stress progresses, Co may compete with $\mathrm{Fe}$ or $\mathrm{Mg}$ in the chloroplast by decreasing chlorophyll content (Lwalaba et al., 2017), which causes Fe deficiency with newly growing leaves to be yellowish in color. As reported by Sree et al. (2015), Co is able to inhibit the activity of enzymes involved in the biosynthesis of chlorophyll intermediates, like 5-aminolevulinic acid and protoporphyrin, which will reduce net photosynthetic activities. Co also adversely affects the translocation of $\mathrm{P}, \mathrm{S}, \mathrm{Cu}, \mathrm{Mn}$, and $\mathrm{Zn}$ from roots to shoots (Chatterjee and Chatterjee, 2000). All these factors, acting together, can result in phytotoxicity and significantly reduce plant growth.

Different plants show different abilities to tolerate Co. Oat (Avena sativa) plants were adversely affected when grown in a soil solution containing $0.14 \mathrm{mg} / \mathrm{L}$ Co (Anderson et al., 1973). Rice (Oryza sativa) plants would develop toxic symptoms when grown in soils with Co ranging from 25 and $50 \mathrm{mg} / \mathrm{kg}$ (Kitagishi and Yamane, 1981). The contents of Co could be used for predicting the development of toxicity (Akeel and Jahan, 2020). Toxic symptoms occurred in bush beans when tissue Co contents ranged from 43 to $142 \mathrm{mg} / \mathrm{kg}$ (Wallace et al., 1977); similarly, $6 \mathrm{mg} / \mathrm{kg}$ in barley seedlings (Davis et al., 1978), and 19 to $32 \mathrm{mg} / \mathrm{kg}$ in Sudan grass (Gough et al., 1979). In general, tissue Co contents between 30 and $40 \mathrm{mg} / \mathrm{kg}$ are considered critical levels for the potential development of Co toxicity (Macnicol and Beckett, 1985). However, due to evolutionary adaptation, Co hyperaccumulators do not develop toxic symptoms at this concentration level. Co contents in leaves of Rinorea cf. bengalensis can be 1,200 mg/kg (Paul et al., 2020), and Glochidion cf. sericeum can accumulate $1,500 \mathrm{mg} / \mathrm{kg}$ Co (Van der Ent et al., 2018). Co hyperaccumulators are not the focus of this article. The reader is referred to publications by Brooks (1977), Brooks et al. (1977, 1980), Baker (1981, 1987), Lange et al. (2017), and Yamaguchi et al. (2019) for more information.

\section{CONCLUSIONS AND FUTURE PERSPECTIVES}

Cobalt in soils ranges from 15 to $25 \mathrm{mg} / \mathrm{kg}$, wherein plant roots can absorb Co from soils and transport absorbed Co from roots to shoots in a controlled manner. Co concentrations in shoots vary with plant species but are comparable to those of essential elements of $\mathrm{Cu}, \mathrm{Ni}$, and $\mathrm{Zn}$. Co was well-documented as a constituent of cobalamin, which is required by symbiotic, endophytic, and associated bacteria in the fixation of $\mathrm{N}_{2}$. Biological $\mathrm{N}$ fixation contributed significantly to the production of economically important crops, including beans, soybeans, rice, corn, barley, wheat, and sugarcane. The current view of plant-microbe association as a phytomicrobiome resulted from millions of years of co-evolution. The coevolution between plants and $\mathrm{N}_{2}$ fixing bacteria should remind us of the critical role Co plays and its potential essentiality to plant growth and development. Additionally, plants must have Co enzymes or proteins that are specifically responsible for Co metabolism. Due to its similar properties to other transition elements, its biological roles in plants have been largely ignored and simply attributed to its ability to substitute for those elements.

Further research is warranted to (1) identify specific roles of Co plays in diazotrophs, with an emphasis on endophytic and associated bacteria, (2) ascertain Co-containing enzymes and proteins that are implicated in metabolisms of both lower and higher plants, (3) determine the interactions of Co with other transition metals in the regulation of enzymatic activities, (4) recognize Co as an essential micronutrient for plant growth, and (5) develop nutrient management programs by incorporating a group of particular $\mathrm{N}$ fixing bacteria with the appropriate amount of Co as plant-specific fertilizers for improving crop production. With the advance in omics, these tasks should be accomplished in the near future. The recognition of Co as an essential micronutrient would enrich our understanding of plant mineral nutrition and enhance crop productivity.

\section{AUTHOR CONTRIBUTIONS}

$\mathrm{XH}, \mathrm{XW}$, and JC wrote the manuscript. JL prepared figures. All authors contributed to the acquisition and interpretation of available literature and the conception of the work, revised the manuscript, and approved this final version.

\section{FUNDING}

This study was supported in part by the Students Innovation and Entrepreneurship Training Program at Zhongkai University of Agriculture and Engineering with grant number 202111347007 and the General Project of the Natural Science Foundation of Fujian Province with grant number 2020J01867.

\section{ACKNOWLEDGMENTS}

The authors would like to thank Ms. Terri A. Mellich for critical review of this manuscript. 


\section{REFERENCES}

Aasfar, A., Bargaz, A., Yaakoubi, K., Hilali, A., Bennis, I., Zeroual, Y., et al. (2021). Nitrogen fixing azotobacter species as potential soil biological enhancers for crop nutrition and yield Stability. Front. Microbiol. 12:628379. doi: $10.3389 /$ fmicb.2021.628379

Abdel-Rahman, H., Salem, A., Moustafa, M. M., and El-Garhy, H. A. (2017). A novice Achromobacter sp. EMCC1936 strain acts as a plant-growth-promoting agent. Acta Physiol. Plant. 39:61. doi: 10.1007/s11738-017-2360-6

Adams, D. G., Bergman, B., Nierzwicki-Bauer, S. A., Duggan, P. S., Rai, A. N., and Schußler, A. (2013). "Cyanobacteria-bryophyte symbioses," in The Prokaryotes, eds M. Dworkin, S. Falkow, E. Rosenberg, K. Schleifer, and E. Stackebrandt (Berlin; Heidelberg: Springer), 359-400.

Aery, N. C., and Jagetiy, B. L. (2000). Effect of cobalt treatments on dry matter production of wheat and DTPA extractable cobalt content in soils. Commun Soil Sci. Plant Anal. 31, 1275-1286. doi: 10.1080/00103620009370512

Ahmed, S., and Evans, H. J. (1959). Effect of Cobalt on growth of soybeans in the absence of supplied nitrogen. Biochem. Biophys. Res. Comm. 1, 271-275. doi: 10.1016/0006-291X(59)90036-1

Ahmed, S., and Evans, H. J. (1960). The plants grown under symbiotic conditions. Proc. Natl. Acad. Sci. U.S.A. 47, 24-36. doi: 10.1073/pnas.47.1.24

Akeel, A., and Jahan, A. (2020). "Role of cobalt in plants: its stress and alleviation," in Contaminants in Agriculture, eds M. Naeem, A. Ansari, and S. Gill (Cham: Springer), 339-352.

Anderson, A., Meyer, D., and Mayer, F. (1973). Heavy metal toxicities: levels of nickel, cobalt and chromium in the soil and plants associated with visual symptoms and variation in growth of an oat crop. Aust. J. Agric. Res. 24, 557-571. doi: 10.1071/AR9730557

Andić, B., Dragićević, S., Stešević, D., Jančić, D., and Krivokapić, S. (2015). Comparative analysis of trace elements in the mosses - Bryum argenteum Hedw. and Hypnum cupressiforme Hedw. in Podgorica (Montenegro). J. Mater. Environ. Sci. 6, 333-342.

Andrews, M., and Andrews, M. E. (2017). Specificity in legume-rhizobia symbioses. Intl. J. Mol. Sci. 18:705. doi: 10.3390/ijms18040705

Antonyuk, L. P., Smirnova, V. E., Kamnev, A. A., Serebrennikova, O. B., Vanoni, M. A., Zanetti, G., et al. (2001). Influence of divalent cations on the catalytic properties and secondary structure of unadenylylated glutamine synthetase from Azospirillum brasilense. Biometals 14, 13-22. doi: 10.1023/A:1016640522299

Arnon, D. I., and Stout, P. R. (1939). The essentiality of certain elements in minute quantity for plants with special reference to copper. Plant Physiol. 14, 371-375. doi: $10.1104 /$ pp.14.2.371

Aslmoshtaghi, E. (2014). Effects of daffodil flowers and cobalt chloride on vase life of cut rose. J. Chem. Health Risks 4, 1-6.

Atta-Aly, M. A. (1998). Soaking summer squash seeds in sow concentrations of cobalt solution before sowing increased plant growth, femaleness, and fruit yield via increasing plant ethylene Level. J. Plant Growth Regul. 17, 25-32 doi: 10.1007/PL00007008

Attia, S. A. A., Gad, N., and Abdel-Rahman., H.M. (2014). Effect of cobalt on growth, yield and production quality with mitotic and meiotic divisions in two onion cultivars. Curr. Sci. Int. 3, 122-131.

Aziz, E. E., Gad, N., and Nadia, M. B. (2007). Effect of cobalt and nickel on plant growth, yield and flavonoid content of Hibiscus sabdariffa L. Aust. J. Basic Appl. Sci. 1, 73-78.

Bageshwar, U. K., Srivastava, M., Pardha-Saradhi, P., Paul, S., Gothandapani, S., Jaat, R. S., et al. (2017). An environmentally friendly engineered Azotobacter strain that replaces a substantial amount of urea fertilizer while sustaining the same wheat yield. Appl. Environ. Microbiol. 83:e00590-17. doi: 10.1128/AEM.00590-17

Baker, A. (1981). Accumulators and excluders-strategies in the response of plants to heavy metals. J. Plant Nutr. 3, 643-654. doi: 10.1080/01904168109362867

Baker, A. (1987). Metal tolerance. New Phytol. 106, 93-111. doi: 10.1111/j.1469-8137.1987.tb04685.x

Baker, A. J. M., Brooks, R. R., Pease, A. J., and Malaisse, F. (1983). Studies on $\mathrm{Cu}$ and cobalt tolerance in three closely related taxa within the genus Silene L. (Caryophyllaceae) from Zare. Plant Soil 73, 377-385. doi: 10.1007/BF02184314

Bakkaus, E., Gouget, B., Gallien, J. P., Khodja, H., Carrot, F., Morel, J. L., et al. (2005). Concentration and distribution of cobalt in higher plants: the use of micro-PIXE spectroscopy. Nucl. Instrum. Methods Phys. Res. Sect. B 231, 350-356. doi: 10.1016/j.nimb.2005.01.082

Barsanti, L., and Gualtieri, P. (2006). Algae: Anatomy, Biochemistry and Biotechnology. Boca Raton, FL: Taylor and Francis Group.

Bartolo, W., and Macey, M. (1989). Cobalt requirement in tissue culture of three species: Brassica oleracea L., Passifora mollissima Bailey, and Saintpaulia ioantha Wendl. J. Hort. Sci. 64, 643-647. doi: 10.1080/14620316.1989.11516003

Basu, M., and Bhadoria, P. B. S. (2008). Performance of groundnut under nitrogen fixing and phosphorous microbial inoculates with different levels of cobalt in alluvial soils of eastern India. Agron. Res. 6, 15-25.

Baxter, I. R., Vitek, O., Lahner, B., Muthukumar, B., Borghi, M., Morrissey, J., et al. (2008). The leaf ionome as a multivariable system to detect a plant's physiological status. Proc. Natl. Acad. Sci. U.S.A. 105, 12081-12086. doi: $10.1073 /$ pnas. 0804175105

Bennett, B. (2010). "EPR of cobalt-substituted zinc enzymes," in Metals in Biology: Application of High Resolution EPR to Metalloenzymes, ed G. R. Hanson (New York, NY: Springer), 345-370. doi: 10.1007/978-1-4419-1139-1

Bertalan, M., Albano, R., de Pádua, V., Rouws, L., Rojas, C., Hemerly, A., et al. (2009). Complete genome sequence of the sugarcane nitrogen-fixing endophyte Gluconacetobacter diazotrophicus Pal5. BMC Genomics 10:450. doi: 10.1186/1471-2164-10-450

Bertrand, G. (1912). On the Role of Trace Substances in Agriculture. Concord, NH: Rumford.

Bhosale, S., Rao, M., and Deshpande, V. (1996). Molecular and industrial aspects of glucose isomerase. Microbiol. Rev. 60, 280-300.

Boddey, R. M., and Dobereiner, J. (1988). Nitrogen fixation associated with grasses and cereals: recent results and perspectives for future research. Plant Soil 108, 53-65. doi: 10.1007/BF02370099

Böhme, H. (1998). Regulation of nitrogen fixation in heterocyst-forming cyanobacteria. Trends Plant Sci. 3. doi: 10.1016/S1360-1385(98)01290-4

Bolle-Jones, E., and Mallikarjuneswara, V. (1957). A beneficial effect of Co on the growth of the rubber plant. Nature 179, 738-739. doi: 10.1038/179738a0

Bridwell-Rabb, J., and Drennan, C. (2017). Vitamin B12 in the spotlight again. Curr. Opin. Chem. Biol. 37, 63-70. doi: 10.1016/j.cbpa.2017.01.013

Brooks, R. R. (1977). Copper and cobalt uptake by Haumaniastrum species. Plant Soil 48, 541-544. doi: 10.1007/BF02187261

Brooks, R. R. (1998). Plants that Hyperaccumulate Heavy, Metals: Their Role in Phytoremediation, Microbiology, Archaeology, Mineral Exploration and Phytomining. Oxon: CAB International.

Brooks, R. R., McCleave, J. A., and Schofield, E. K. (1977). Cobalt and nickel uptake by the Nyssaceae. Taxon 26, 197-201. doi: 10.2307/1220551

Brooks, R. R., Reeves, R. D., Morrison, R. S., and MalaJsse, F. (1980). Hyperaccumulation of copper and cobalt: a review. Bull. Soc. Roy. Bot. Belg. $113,166-172$.

Brylinski, M., and Skolnick, J. (2011). FINDSITE-metal: integrating evolutionary information and machine learning for structure-based metal binding site prediction at the proteome level. Proteins 79, 735-751. doi: 10.1002/prot. 22913

Bulantseva, E. A., Glinka, E. M., Protsenko, M. A., and Sal'kova, E. G. (2001). A protein inhibitor of polygalacturonase in apple fruits treated with aminoethoxyvinylglycine and cobalt chloride. Prikl. Biokhim. Mikrobiol. 37, 100-104. doi: 10.1023/A:1002808912247

Carpenter, K. J. (2004). The Nobel Prize and the Discovery of Vitamins. NobelPrize.org. Nobel Prize Outreach AB2021. Stockholm. Available online at: https://www.nobelprize.org/prizes/themes/the-nobel-prize-and-thediscovery-of-vitamins (accessed August 28, 2021).

Carter, E. L., Flugga, N., Boer, J. L., Mulrooney, S. B., and Hausinger, R. P. (2009). Interplay of metal ions and urease. Metallomics 1, 207-221. doi: 10.1039/b903311d

Cavet, J. S., Borrelly, G. P., and Robinson, N. J. (2003). Zn, Cu and Co in cyanobacteria: selective control of metal availability. FEMS Microbiol. Rev. 27, 165-181. doi: 10.1016/S0168-6445(03)00050-0

Chang, A. C. G., Chen, T., Li, N., and Duan, J. (2019). Perspectives on endosymbiosis in coralloid roots: association of cycads and cyanobacteria. Front. Microbiol. 10:1888. doi: 10.3389/fmicb.2019. 01888

Chang, E., Simmers, C., and Knight, D. (2010). Cobalt complexes as antiviral and antibacterial agents. Pharmaceuticals 3, 1711-1728. doi: 10.3390/ph3061711 
Chatel, D. L., Robson, A. D., Gartrell, J. W., and Dilworth, M. J. (1978). The effect of inoculation on cobalt application on the growth of and nitrogen fixation of sweet lupins. Aust. J. Agric. Res. 29, 1191-1202. doi: 10.1071/AR9781191

Chatterjee, J., and Chatterjee, C. (2000). Phytotoxicity of cobalt, chromium and copper in caulifower. Environ. Pollut. 109, 69-74. doi: 10.1016/S0269-7491(99)00238-9

Chen, J., Zhou, J., and Goldsbrough, P. (1997). Characterization of phytochelatin synthase from tomato. Physiol. Plant 101, 165-192. doi: 10.1111/j.1399-3054.1997.tb01833.x

Cheng, Y. S., Yan, Y. B., and Liu, J. Y. (2005). Spectroscopic characterization of metal bound phytochelatin analogue (Glu-Cys)(4)-Gly. J. Inorg. Biochem. 99, 1952-1962. doi: 10.1016/j.jinorgbio.2005.06.016

Chmielowska-Bak, J., Lefèvre, I., Lutts, S., Kulik, A., and Deckert, J. (2014). Effect of cobalt chloride on soybean seedlings subjected to cadmium stress. Acta Soc. Bot. Pol. 83, 201-207. doi: 10.5586/asbp.2014.027

Choudhury, A., and Kennedy, I. (2004). Prospects and potentials for systems of biological nitrogen fixation in sustainable rice production. Biol. Fertil. Soils 39, 219-227. doi: 10.1007/s00374-003-0706-2

Choudhury, F. K., Rivero, R. M., Blumwald, E., and Mittler, R. (2017). Reactive oxygen species, abiotic stress and stress combination. Plant J. 90, 856-867. doi: $10.1111 /$ tpj.13299

Ciotea, D., Ungureanu, E., Mustatea, G., and Popa, M. E. (2021). Incidence of lead, cadmium, chromium, nickel and cobalt in basil, rosemary and peppermint seasonings from Romanian market. Bull. Univ. Agric. Sci. Vet. Med. ClujNapoca. Food Sci. Technol. 78, 19-32. doi: 10.15835/buasvmcn-fst:2021.0002

Collins, R. N., Bakkaus, E., Carrière, M., Khodja, H., Proux, O. and, Morel, J. L., et al. (2010). Uptake, localization, and speciation of cobalt in Triticum aestivum L. (wheat) and Lycopersicon esculentum M. (tomato). Environ. Sci. Technol. 44, 2904-2910. doi: 10.1021/es903485h

Compant, S., Kaplan, H., Sessitsch, A., Nowak, J., Ait Barka, E., and Clément, C. (2008). Endophytic colonization of Vitis vinifera L. by Burkholderia phytofirmans strain PSJN: from the rhizosphere to inflorescence tissues. FEMS Microbiol. Ecol. 63, 84-93. doi: 10.1111/j.1574-6941.2007.00410.x

Conte, S. S., and Walker, E. L. (2011). Transporters contributing to iron trafficking in plants. Mol. Plant 4, 1-13. doi: 10.1093/mp/ssr015

Croft, M. T., Lawrence, A. D., Raux-Deery, E., Warren, M. J., and Smith, A. G. (2005). Algae acquire vitamin B12 through a symbiotic relationship with bacteria. Nature 438, 90-93. doi: 10.1038/nature04056

Cruz-Lopez, R., and Maske, H. (2016). The vitamin B1 and B12 required by the marine dinoflagellate lingulodinium polyedrum Can be provided by its associated bacterial community in culture. Front. Microbiol. 7:560. doi: 10.3389/fmicb.2016.00560

Czerpak, R., Bajguz, A., Chodkowski, K., and Popow, H. (1994). Influence of nickel and cobalt on the growth and biochemical changes of Chlorella pyrenoidosa (Chlorophyceae). Pol. Arch. Hydrobiol. 41, 161-169.

Das, H. K. (2019). Azotobacters as biofertilizer. Adv. Appl. Microbiol. 108, 1-43. doi: 10.1016/bs.aambs.2019.07.001

Davies, K. M., Jibran, R., Zhou, Y., Albert, N. W., Brummell, D. A., Jordan, B. R., et al. (2020). The evolution of flavonoid biosynthesis: a bryophyte perspective. Front. Plant Sci. 11:7. doi: 10.3389/fpls.2020.00007

Davis, R., Beckett, P., and Wollan, E. (1978). Critical levels of twenty potentially toxic elements in young spring barley. Plant Soil 49, 395-408. doi: 10.1007/BF02149747

Dewey, D. W., Lee, H. J., and Marston, H. R. (1958). Provision of cobalt to ruminants by means of heavy pellets. Nature 181, 1367-1371. doi: $10.1038 / 1811367 \mathrm{a} 0$

Dilworth, M. J., Robson, A. D., and Chatel, D. L. (1979). Cobalt and nitrogen fixation in Lupinus angustifolius L. II. Nodule formation and function. New Phytol. 83, 63-79. doi: 10.1111/j.1469-8137.1979.tb00727.x

Din, M., Nelofer, R., Salman, M., Abdullah, K., F. H., and Khan, A. (2019). Production of nitrogen fixing Azotobacter (SR-4) and phosphorus solubilizing Aspergillus niger and their evaluation on Lagenaria siceraria and Abelmoschus esculentus. Biotechnol. Rep. 22:e00323. doi: 10.1016/j.btre.2019.e 00323

Dobereiner, J., Reis, V., Paula, M., and Olivares, F. (1993). "Endophytic diazotrophs in sugarcane cereals and tuber crops," in New Horizons in Nitrogen Fixation, eds R. Palacios, J. Moor, and W. Newton (Dordrecht: Kluwer), 671-674.
Doxey, A. C., Kurtz, D. A., Lynch, M. D., Sauder, L. A., and Neufeld, J. D. (2015). Aquatic metagenomes implicate Thaumarchaeota in global cobalamin production. ISME J. 9, 461-471. doi: 10.1038/ismej.2014.142

Eitinger, T. (2013). "Cobalt transporters," in Encyclopedia of Metalloproteins, eds R. H. Kretsinger, V. N. Uversky, and E. A. Permyakov (New York, NY: Springer), 678-682.

El-Essawy, A., El-Sayed, M., and Mohamed, Y. (1984). Production of cyanocobalamine by Azotobacter chroococcum. Zentralblatt für Mikrobiol. 139, 335-342. doi: 10.1016/S0232-4393(84)80011-6

Elledge, S., Zhou, Z., and Allen, J. (1992). Ribonucleotide reductase: regulation, regulation, regulation. Trends. Biochem. Sci 17, 119-123. doi: 10.1016/0968-0004(92)90249-9

Erdman, J. A., and Modreski, P. J. (1984). Copper and cobalt in aquatic mosses and stream sediments from the Idaho Cobalt Belt. J. Geochem. Explor. 20, 75-84. doi: 10.1016/0375-6742(84)90091-8

Evans, H. J., and Kliewer, M. (1964). Vitamin B12 compounds in relation to the requirements of cobalt for higher plants and nitrogen-fixing organisms. Annals N. Y. Acad. Sci. 112, 735-755. doi: 10.1111/j.1749-6632.1964.tb45052.x

Falcón, L., Magallón, S., and Castillo, A. (2010). Dating the cyanobacterial ancestor of the chloroplast. ISME J. 4,777-783. doi: 10.1038/ismej.2010.2

Fang, H., Kang, J., and Zhang, D. (2017). Microbial production of vitamin B12: a review and future perspectives. Microb. Cell. Fact. 16:15. doi: 10.1186/s12934-017-0631-y

Faucon, M. P., Shutcha, M. N., and Meerts, P. (2007). Revisiting copper and cobalt concentrations in supposed hyperaccumulators from SC Africa: influence of washing and metal concentrations in soil. Plant Soil 301, 29-36. doi: 10.1007/s11104-007-9405-3

Franche, C., Lindstrom, K., and Elmerich, C. (2009). Nitrogen- fixing bacteria associated with leguminous and non-leguminous plants. Plant Soil 321, 35-59. doi: 10.1007/s11104-008-9833-8

Fujino, D. W., and Reid, M.S. (1983). Factors affecting the vase life of fronds of maidenhair fern. Sci. Hort. 21, 181-188. doi: 10.1016/0304-4238(83)90164-4

Gad, N. (2006). Increasing the efficiency of nitrogen fertilization through cobalt application to pea plant. Res. J. Agri. Biol. Sci. 2, 433-442.

Gad, N. (2012a). Physiological and chemical response of groundnut (Arachis hypogaea) to Cobalt Nutrition. World Appl. Sci. J. 20, 327-335.

Gad, N. (2012b). Role and importance of cobalt nutrition on groundnut (Arachis hypogaea) production. World Appl. Sci. J. 20, 359-367. doi: 10.5829/idosi.wasj.2012.20.03.2819

Gad, N., and Hassan, N. M. K. (2013). Role of cobalt and organic fertilizers amendments on tomato production in the newly reclaimed soil. World Appl. Sci. J. 22, 1527-1533.

Gad, N., and Kandil, H. (2008). Response of sweet potato (Ipomoea batatas L.) plants to different levels of cobalt. Aust. J. Basic Appl. Sci. 2, 949-955.

Gad, N., and Kandil, H. (2009). The influence of cobalt on sugar beet (Beta vulgaris L.) production. Intl. J. Acad. Res. 1, 52-58.

Garcia, M. M., Pereira, L. C., Braccini, A. L., Angelotti, P., Suzukawa, A. K., Marteli, D. C., et al. (2017). Effects of Azospirillum brasilense on growth and yield compounds of maize grown at nitrogen limiting conditions. Revista de Ciências Agrárias 40, 353-362. doi: 10.19084/RCA16101

García-Caparrós, P., De Filippis, L., Gul, A., Hasanuzzaman, M., Ozturk, M., Altay, V., et al. (2020). Oxidative stress and antioxidant metabolism under adverse environmental conditions: a review. Bot. Rev. 40, 353-362. doi: 10.1007/s12229-020-09231-1

Garnham, G. W., Codd, G. A., and Gadd, G. M. (1992). Kinetics of uptake and intracellular location of cobalt, manganese and zinc in the estuarine green alga Chlorella salina. Appl. Microbiol. Biotechnol. 37, 270-276. doi: $10.1007 / \mathrm{BF} 00178183$

Gerlach, M., and Vogel, I. (1902). Stickstoffsammelden bakterien. Z. Bakterien II 8:669.

Giglione, C., and Meinnel, T. (2001). Organellar peptide deformylases: universality of the N-terminal methionine cleavage mechanism. Trends Plant Sci. 6, 566-572. doi: 10.1016/S1360-1385(01)02151-3

Giglione, C., Serero, A., Pierre, M., Boisson, B., and Meinnel, T. (2000). Identification of eukaryotic peptide deformylases reveals universality of N-terminal protein processing mechanisms. EMBO J. 19, 5916-5929. doi: $10.1093 / \mathrm{emboj} / 19.21 .5916$ 
Gonzalez-Lopez, J., Salmeron, V., Moreno, J., and Ramos-Cormenzana, A. (1983). Amino acids and vitamins produced by Azotobacter vinelandii ATCC 12837 in chemically-defined media and dialysed soil media. Soil Biol. Biochem. 15, 711-713. doi: 10.1016/0038-0717(83)90037-8

Gonzalez-Montana, J. R., Escalera-Valente, F., Alonso, A. J., Lomillos, J. M., Robles, R., and Alonso, M. E. (2020). Relationship between vitamin B12 and cobalt metabolism in domestic ruminant: an update. Animals 10:1855. doi: 10.3390/ani10101855

Gough, L., Shacklette, H., and Case, A. (1979). Element concentrations toxic to plants, animals and man. LiSGS Bull 1466, 80-84.

Govindaraju, K. (1994). Compilation of working values and sample description for 383 geostandards. Geostand Newslett. 18, 1-158. doi: 10.1111/j.1751-908X.1994.tb00502.x

Grover, S., and Purves, W. K. (1976). Cobalt and plant development: interactions with ethylene in hypocotyl growth. Plant Physiol. 57, 886-889. doi: $10.1104 /$ pp.57.6.886

Grube, M., Seckbach, J., and Muggia, L. (2017). Algal and Cyanobacteria Symbioses. Singapore: World Scientific.

Guo, M., and Chen, Y. (2018). Coenzyme cobalamin: biosynthesis, overproduction and its application in dehalogenation-a review. Rev. Environ. Sci. Biotechnol. 17, 259-284. doi: 10.1007/s11157-018-9461-6

Gupta, G., Panwar, J., Akhtar, M. S., and Jha, P. N. (2012). "Endophytic nitrogenfixing bacteria as biofertilizer," in Sustainable Agriculture Reviews, ed E. Lichtfouse (Dordrecht: Springer), 183-221.

Gupta, V., Roper, M., and Roget, D. (2006). Potential for non-symbiotic N2fixation in different agroecological zones of southern Australia. Aust. J. Soil Res. 44, 343-354. doi: 10.1071/SR05122

Hamilton, E. I. (1994). The geobiochemistry of cobalt. Sci. Total Environ. 150, 7-39. doi: 10.1016/0048-9697(94)90126-0

Han, H. Y., Xu, W. A., Lu, Z. R., Zou, F., and Li, S. (2008). Activation and inactivation of horseradish peroxidase by cobalt ions. J. Biomol. Struct. Dyn. 26, 83-92. doi: 10.1080/07391102.2008.10507226

Hansen, B., Thorling, L., Schullehner, J., Termansen, M., and Dalgaard, T. (2017). Groundwater nitrate response to sustainable nitrogen management. Sci. Rep. 7:8566. doi: 10.1038/s41598-017-07147-2

Harrop, T. C., and Mascharak, P. K. (2013). "Cobalt-containing enzymes," in Encyclopedia of Metalloproteins, eds R. H. Kretsinger, V. N. Uversky, and E. A. Permyakov (New York, NY: Springer), 684-690.

Hartmann, A., Stoffels, M., Eckert, B., Kirchhof, G., and Schloter, M. (2000). "Analysis of the presence and diversity of diazotrophic endophytes," in Prokaryotic Nitrogen Fixation: A Model System for the Analysis of a Biological Process, ed E. W. Triplett (Wymondham: Horizon Scientific Press), 727-736.

Hasanuzzaman, M., Bhuyan, M. H. M. B., Zulfiqar, F., Raza, A., Mohsin, S. M., Mahmud, J. A., et al. (2020). Reactive oxygen species and antioxidant defense in plants under abiotic stress: revisiting the crucial role of a universal defense regulator. Antioxidants 9:681. doi: 10.3390/antiox9080681

Havlin, J. L., Tisdale, S. L., Nelson, W. L., and Beaton, J. D. (2013). Soil Fertility and Fertilizers. Upper Saddle River, NJ: Prentice Hall, Inc.

Hawco, N. J., McIlvin, M. M., Bundy, R. M., Tagliabue, A., Goepfert, T. J., Moran, D. M., et al. (2020). Minimal cobalt metabolism in the marine cyanobacterium Prochlorococcus. Proc. Natl. Acad. Sci. 117, 15740-15747. doi: $10.1073 /$ pnas.2001393117

Heal, K. R.,Wei, Q., Ribalet, F., Bertagnolli, A. D., Coyote-Maestas, W., Hmelo, L. R., et al. (2017). Two distinct pools of B12 analogs reveal community interdependencies in the ocean. Proc. Natl. Acad. Sci. U.S.A. 114, 364-369. doi: $10.1073 /$ pnas. 1608462114

Helmy, L. M., and Gad, N. (2002). Effect of cobalt fertilization on the yield, quality the essential oil composition of parsley leaves. Arab. Univ. J. Agric. Sci. Ain. Shams Univ Cairo 10, 779-802.

Herridge, D. F., Peoples, M. B., and Boddey, R. M. (2008). Global inputs of biological nitrogen fixation in agricultural systems. Plant Soil 311, 1-18. doi: $10.1007 /$ s11104-008-9668-3

Hewitt, E. J., and Bond, G. (1966). The cobalt requirement of non-legume root nodule plants. J. Exp. Bot. 17, 480-491. doi: 10.1093/jxb/17.3.480

Holm-Hansen, O., Gerloff, G. C., and Skoog, F. (1954). Cobalt as an essential element for blue-green algae. Physiol. Plant 7, 665-675. doi: 10.1111/j.1399-3054.1954.tb07727.x
Homer, F. A. (1991). Comparative studies of nickel, cobalt, and copper uptake by some nickel hyperaccumulators of the genus Alyssum. Plant Soil 138, 195-205. doi: 10.1007/BF00012246

Hopkins, W. (1995). Introduction to Plant Physiology. New York, NY: John Wiley and Sons.

Hurek, T., and Reinhold-Hurek, B. (2003). Azoarcus sp. strain BH72 as a model for nitrogen-fixing grass endophytes. J. Biotechnol. 106, 169-178. doi: 10.1016/j.jbiotec.2003.07.010

Huss-Danell, K. (1997). Tansley Review No. 93. Actinorhizal symbioses and their N2 fixation. New Phytol. 136, 375-405. doi: 10.1046/j.1469-8137.1997.00755.x

Huwait, A. E., Kumosani, A. T., Moselhy, S. S., Mosaoa, M. R., and Yaghmoor, S. S. (2015). Relationship between soil cobalt and vitamin B12 levels in the liver of livestock in Saudi Arabia: role of competing elements in soils. Afr. Health Sci. 15, 993-998. doi: 10.4314/ahs.v15i3.38

Hyodo, H., and Fukasawa, R. (1985). Ethylene production in kiwi fruit (Actinidia chinensis cultivar. Hayward). J. Jap. Soc. Hortic. Sci. 54, 209-215. doi: 10.2503/jjshs.54.209

Iswaran, V., and Rao Sundara, W. V. B. (1964). role of cobalt in Nitrogen fixation by Azotobacter chroococcum. Nature 203:549. doi: 10.1038/203549a0

Jaleel, C. A., Jayakumar, K., Zhao, C.-X., and Iqbal, M. (2009). Low concentration of cobalt increases growth, biochemical constituents, mineral status and yield in Zea mays. J. Sci. Res. 1, 128-137. doi: 10.3329/jsr.v1i1.1226

Jalilian, N., Najafpour, G., and Khajouei, M. (2019). Enhanced vitamin B12 production using Chlorella vulgaris. IJE Transac. Basics 32, 1-9. doi: 10.5829/ije.2019.32.01a.01

Jamali, B., and Rahemi, M. (2011). Carnation flowers senescence as influenced by nickel, cobalt and silicon. J. Biol. Environ. Sci. 5, 147-152.

James, E. K., Olivares, F. L., de Oliveira, A. L., dos Reis F. B. Jr., da Silva, L. G., and Reis, V. M. (2001). Further observations on the interaction between sugar cane and Gluconacetobacter diazotrophicus under laboratory and greenhouse conditions. J. Exp. Bot. 52, 747-760. doi: 10.1093/jexbot/52.357.747

Jayakumar, K., Abdul, Jaleel, C., Azooz, M. M., Vijayarengan, P., Gomathinayagam, M., and Panneerselvam, R. (2009). Effect of different concentrations of cobalt on morphological parameters and yield components of soybean. Glob. J. Mol. Sci. $4,10-14$

Jayakumar, K., Rajesh, M., Baskaran, L., and Vijayarengan, P. (2013). Changes in nutritional metabolism of tomato plants exposed to increasing concentration of cobalt chloride. Acta Physiol. Plant. 4, 62-69.

Jensen, E. L., Maberly, S. C., and Gontero, B. (2020). Insights on the functions and ecophysiological relevance of the diverse carbonic anhydrases in microalgae. Int. J. Mol. Sci. 21:2922. doi: 10.3390/ijms21082922

Johansson, C., and Bergman, B. (1994). Reconstitution of the symbiosis of Gunnera manicata Linden: cyanobacterial specificity. New Phytol. 126, 643-652. doi: 10.1111/j.1469-8137.1994.tb02960.x

Kabata-Pendias, A., and Mukherjee, A. B. (2007). Trace Elements From Soils to Human. Berlin; Heidelberg: Springer-Verlag.

Kamnev, A., Tarantilis, P., Antonyuk, L., Bespalova, L., Polissiou, M., Colina, M., et al. (2001). Fourier transform Raman spectroscopic characterisation of cells of the plant-associated soil bacterium Azospirillum brasilense Sp7. J. Mol. Struct. 563, 199-207. doi: 10.1016/S0022-2860(00)00877-2

Kannan, T., and Ponmurugan, P. (2010). Response of paddy (Oryza sativa L.) varieties to Azospirillum brasilense inoculation. J. Phytol. 2, 8-13.

Kazemi, M. (2012). Effect of cobalt, silicon, acetylsalicylic acid and sucrose as novel agents to improve vase-life of Argyranthemum flowers. Trends Appl. Sci. Res. 7, 579-583. doi: 10.3923/tasr.2012.579.583

Kazemi, M., and Ameri, A. (2012). Effect of Ni, CO, SA and sucrose on extending the vase-life of lily cut flower. Iran. J. Energy Environ. 3, 162-166. doi: 10.5829/idosi.ijee.2012.03.02.0258

Ke, J., Wang, B., and Yoshikuni, Y. (2021). Microbiome engineering: synthetic biology of plant-associated microbiomes in sustainable agriculture. Trends Biotechnol. 39, 244-261. doi: 10.1016/j.tibtech.2020.07.008

Kellogg, M. M., Mcllvin, M. R., Vedamati, J., Twining, B. S., Moffett, J. W., Marchetti, A., et al. (2020). Efficient zinc/cobalt inter-replacement in northeast Pacific diatoms and relationships to high surface dissolved Co: Zn ratio. Limnol. Oceanogr. 65, 2557-2582. doi: 10.1002/lno.11471

Keshavarz, H., and Moghadam, R. S. G. (2017). Seed priming with cobalamin (vitamin B12) provides significant protection against salinity stress in the common bean. Rhizosphere 3, 143-149. doi: 10.1016/j.rhisph.2017.04.010 
Khan, A. R., Park, G. S., Asaf, S., Hong, S. J., Jung, B. K., and Shin, J. H. (2017). Complete genome analysis of Serratia marcescens RSC-14: a plant growthpromoting bacterium that alleviates cadmium stress in host plants. PloS ONE 12:e0171534. doi: 10.1371/journal.pone.0171534

Khrustalev, V., Khrustaleva, T., Poboinev, V., Karchevskaya, C., Shablovskaya, E., and Terechova, T. (2019). Cobalt(ii) cation binding by proteins. Metallomics 11, 1743-1752. doi: 10.1039/C9MT00205G

Kirchhof, G., Reis, V., Baldani, J., Eckert, B., Döbereiner, J., and Hartmann, A. (1997). Occurrence, physiological and molecular analysis of endophytic diazotrophic bacteria in gramineous energy plants. Plant Soil 194, 45-55. doi: 10.1023/A:1004217904546

Kitagishi, K., and Yamane, I. (1981). Heavy Metal Pollution in Soils of Japan. Tokyo: Japan Science Society Press.

Kliewer, M., and Evans, H. (1963a). Cobamide coenzyme contents of soybean nodules and nitrogen fixing bacteria in relation to physiological conditions. Plant Physiol. 38, 99-104. doi: 10.1104/pp.38.1.99

Kliewer, M., and Evans, H. J. (1963b). Identification of cobamide coenzyme in nodules of symbionts and isolation of the B12 coenzyme from Rhizobium meliloti. Plant Physiol. 38, 55-59. doi: 10.1104/pp.38.1.55

Kobayashi, M., and Shimizu, S. (1999). Cobalt proteins. Eur. J. Biochem. 261, 1-9. doi: 10.1046/j.1432-1327.1999.00186.x

Kolberg, M., Strand, K. R., Graff, P., and Andersson, K. K. (2004). Structure, function, and mechanism of ribonucleotide reductases. Biochim. Biophys. Acta 1699, 1-34. doi: 10.1016/S1570-9639(04)00054-8

Koleli, N., Demir, A., Kantar, C., Atag, G. A., Kusvuran, K., and Binzet, R. (2015). "Heavy metal accumulation in serpentine flora of Mersin-Findikpinari (Turkey) - Role of ethylenediamine tetraacetic Acid in facilitating extraction of nickel," in Soil Remediation and Plants (New York, NY, USA, Academic Press). doi: 10.1016/b978-0-12-799937-1.00022-x

Korshunova, Y. O., Eide, D., Clark, W. G., Guerinot, M. L., and Pakrasi, H. B. (1999). The IRT1 protein from Arabidopsis thaliana is a metal transporter with a broad substrate range. Plant Mol. Biol. 40, 37-44. doi: 10.1023/A:1026438615520

Krause, A., Ramakumar, A., Bartels, D., Battistoni, F., Bekel, T., Boch, J., et al. (2006). Complete genome of the mutualistic, N 2-fixing grass endophyte Azoarcus sp. strain BH72. Nat. Biotechnol. 24, 1384-1390. doi: 10.1038/nbt1243

Kubota, Y., Shoji, S., and Motohara, K. (1977). Purification and properties of prolidase for germinating soybeans. Yakugaku Zasshi 97, 111-115. doi: 10.1248/yakushi1947.97.1_111

Lange, B., van der Ent, A., Baker, A. J., Echevarria, G., Mahy, G., Malaisse, F., et al. (2017). Copper and cobalt accumulation in plants: a critical assessment of the current state of knowledge. New Phytol. 213, 537-551. doi: 10.1111/nph.14175

Lau, O. L., and Yang, S. F. (1976). Inhibition of ethylene production by cobaltous ion. Plant Physiol. 58, 114-117. doi: 10.1104/pp.58.1.114

Lawrence, A. D., Nemoto-Smith, E., Deery, E., Baker, J. A., Schroeder, S., Brown, D. G., et al. (2018). Construction of fluorescent analogs to follow the uptake and distribution of cobalamin (vitamin B12) in bacteria, worms, and plants. Cell Chem. Biol. 25, 941-951. e946. doi: 10.1016/j.chembiol.2018.04.012

Lee, H. J. (1951). Cobalt and copper deficiencies affecting sheep in South Australia. J. Agri. Sci. Austr. 54, 475-532.

Li, H., Liu, Y., Qin, H., Lin, X., Tang, D., Wu, Z., et al. (2020). A rice chloroplast-localized ABC transporter ARG1 modulates cobalt and nickel homeostasis and contributes to photosynthetic capacity. New Phytol. 228, 163-178. doi: 10.1111/nph.16708

Lindsay, D., and Kerr, W. (2011). Cobalt close-up. Nat. Chem. 3:494. doi: $10.1038 /$ nchem. 1053

Liu, J. (1998). Cobalt: physiological effects and uptake mechanisms in plants [Ph.D. thesis]. The University of Adelaide, Adelaide, SA, Australia.

Lwalaba, J. L. W., Zvogbo, G., Mulembo, M., Mundende, M., and Zhang, G. (2017). The effect of cobalt stress on growth and physiological traits and its association with cobalt accumulation in barley genotypes differing in cobalt tolerance. J. Plant. Nutr. 40, 2192-2199. doi: 10.1080/01904167.2017.1346676

Lyu, S., Wei, X., Chen, J., Wang, C., Wang, X., and Pan, D. (2017). Titanium as a beneficial element for crop production. Front. Plant. Sci. 8:597. doi: 10.3389/fpls.2017.00597

Macnicol, R., and Beckett, P. (1985). Critical tissue concentrations of potentially toxic elements. Plant Soil 85, 107-129. doi: 10.1007/BF02197805
Mahey, S., Kumar, R., Sharma, M., Kumar, V., and Bhardwaj, R. (2020). A critical review on toxicity of cobalt and its bioremediation strategies. SN Appl. Sci. 2:1279. doi: 10.1007/s42452-020-3020-9

Malik, M., Chaney, R. L., Brewer, E. P., Li, Y. M., and Angle, J. S. (2000) Phytoextraction of Soil Cobalt Using Hyperaccumulator Plants. Int. J. Phytorem. 2, 319-329. doi: 10.1080/15226510008500041

Mandujano-Piña, M., Colinas-León, M. T., Castillo-González, A. M., AlíaTejacal, I., and Valdéz-Aguilar, L. A. (2012). Cobalt as senescence retardant in postharvest of oriental hybrid Lilium. Revista Chapingo. Serie Hort. 18, 239-252. doi: 10.5154/r.rchsh.2010.09.034

Maret, M., and Vallee, B. (1993). Cobalt as probe and label of proteins. Methods Enzymol. 226, 52-71. doi: 10.1016/0076-6879(93)26005-T

Marschner, P. (2011). Marschner's Mineral Nutrition of Higher Plants. Amsterdam: Elsevier/Academic Press.

Marsh, E. N. (1999). Coenzyme B12 (cobalamin)-dependent enzymes. Essays Biochem. 34, 139-154. doi: 10.1042/bse0340139

Marsh, E. N. G., and Drennan, C. L. (2001). Adenosyl cobalamin dependent isomerases: new insights into structure and mechanism. Curr. Opin. Chem. Biol. 5, 499-505. doi: 10.1016/S1367-5931(00)00238-6

McLeod, K. W., and Ciravolo, T. G. (2007). Cobalt uptake by Nyssa aquatica, N. sylvatica var. biflora, and Taxodium distichum seedlings. Wetlands 27, 40-43. doi: 10.1672/0277-5212(2007)27[40:CUBNAN]2.0.CO;2

Mehrafarin, A., Rezazadeh, S., Naghdi Badi, H., Gh, N., Z, E., and Qaderi, A. (2021). A review on biology, cultivation and biotechnology of fenugreek (Trigonella foenum-graecum L.) as a valuable medicinal plant and multipurpose. J. Med. Pl. $10,6-24$.

Mohandas, S. (1985). Effect of presowing seed treatment with molybdenum and cobalt on growth, nitrogen and yield in bean (Phaseolus vulgaris L.). Plant Soil 86, 283-285. doi: 10.1007/BF02182905

Morel, M., Crouzet, J., Gravot, A., Auroy, P., Leonhardt, N., Vavasseur, A., et al. (2009). AtHMA3, a P1B-ATPase allowing $\mathrm{Cd} / \mathrm{Zn} / \mathrm{Co} / \mathrm{Pb}$ vacuolar storage in Arabidopsis. Plant Physiol. 149, 894-904. doi: 10.1104/pp.108.130294

Morrison, R. S. (1979). Copper and cobalt uptake by metallophytes from Zaïre. Plant Soil 53, 535-539. doi: 10.1007/BF02140724

Morrissey, J., Baxter, I., Lee, J., Li, L., Lahner, B., Grotz, N., et al. (2009). The ferroportin metal efflux proteins function in iron and cobalt homeostasis in Arabidopsis. Plant Cell 21, 3326-3338. doi: 10.1105/tpc.109.069401

Mozafar, A. (1994). Enrichment of some B-vitamins in plants with application of organic fertilizers. Plant Soil 167, 305-331. doi: 10.1007/BF00007957

Murr, D. P., Venkatarayappa, T., and Tsujita., M. J. (1979). Counteraction of bent-neck of cut roses with cobalt nitrate." Can. J. Plant Sci. 59, 1169-1171. doi: $10.4141 /$ cjps79-184

Muthukumarasamy, R., Cleenwerck, I., Revathi, G., Vadivelu, M., Janssens, D., Hoste, B., et al. (2005). Natural association of Gluconacetobacter diazotrophicus and diazotrophic Acetobacter peroxydans with wetland rice. Syst. Appl. Microbiol. 28, 277-286. doi: 10.1016/j.syapm.2005.01.006

Nagpal, N. (2004). Water Quality Guidelines for Cobalt. Victoria, BC: Ministry of Water, Land and Air Protection, Water Protection Section, Water, Air and Climate Change Branch.

Nakos, M., Pepelanova, I., Beutel, S., Krings, U., Berger, R. G., and Scheper, T. (2017). Isolation and analysis of vitamin B12 from plant samples. Food Chem. 216, 301-308. doi: 10.1016/j.foodchem.2016.08.037

Nicholas, D., Kobayashi, M., and Wilson, P. (1962). Cobalt requirement for inorganic nitrogen metabolism in microorganisms. Proc. Nat. Acad. Sci. 48, 1537-1542. doi: 10.1073/pnas.48.9.1537

Nohwar, N., Khandare, R. V., and Desai, N. S. (2020). Media optimization studies and production of adenosylcobalamin (Vitamin B12) by environment friendly organism Rhizobium spp. J. Appl. Biol. Biotech. 8, 38-47.

Odaka, M., and Kobayashi, M. (2013). "Cobalt proteins, overview," in Encyclopedia of Metalloproteins, eds R. H. Kretsinger, V. N. Uversky, and E. A. Permyakov (New York, NY: Springer), 670-678.

Orji, J., Ngumah, C., Asor, H., and Anuonyemere, A. (2018). Effects of cobalt and manganese on biomass and nitrogen fixation yields of a free-living nitrogen fixer-Azotobacter chroococcum. Eur. J. Biol. Res. 8, 7-13.

Osman, D., Cooke, A., Young, T., Deery, E., Robinson, N., and Warren, M. (2021). The requirement for cobalt in vitamin $\mathrm{B} 12$ : a paradigm for protein metalation. BBA-Mol. Cell. Res. 1868:118896. doi: 10.1016/j.bbamcr.2020.118896 
Ozanne, P. G., Greenwood, E. A. N., and Shaw, T. C. (1963). The cobalt requirement of Subterranean clover in the field. Aust. J. Agric. Res. 14, 39-50. doi: 10.1071/AR9630039

Page, V., and Feller, U. (2005). Selective transport of zinc, manganese, nickel, cobalt and cadmium in the root system and transfer to the leaves in young wheat plants. Ann. bot. 96, 425-434. doi: 10.1093/aob/mci189

Pais, I. (1992). Criteria of essentiality, beneficiality and toxicity of chemical elements. Acta Aliment. 21, 145-152.

Paizs, C., Diemer, T., and Rétey, J. (2008). The putative coenzyme B12- dependent methylmalonyl-CoA mutase from potatoes is a phosphatase. Bioorg. Chem. 36, 261-264. doi: 10.1016/j.bioorg.2008.06.002

Palacios, O. A., Bashan, Y., and de-Bashan, L. E. (2014). Proven and potential involvement of vitamins in interactions of plants with plant growth-promoting bacteria-an overview. Biol. Fertil. Soils. 50, 415-432. doi: 10.1007/s00374-013-0894-3

Paul, A. L. D., Nkrumah, P. N., Echevarria, G., Erskine, P. D., Chaney, R. L., Spiers, K. M., et al. (2020). Cobalt hyperaccumulation in Rinorea cf. Bengalensis (Violaceae) from sabah: Accumulation potential and tissue and cellular-level distribution of cobalt. Plant Soil 455, 289-303. doi: 10.1007/s11104-020-04629-7

Pedrosa, F. O., Monteiro, R. A., Wassem, R., Cruz, L. M., Ayub, R. A., Colauto, N. B., et al. (2011). Genome of Herbaspirillum seropedicae strain SmR1, a specialized diazotrophic endophyte of tropical grasses. PLoS Genet. 7:e1002064. doi: 10.1371/journal.pgen.1002064

Permyakov, E. A. (2021). Metal binding proteins. Encyclopedia 1, 261-292. doi: 10.3390/encyclopedia1010024

Pham, V. T. K., Rediers, H., Ghequire, M. G. K., Nguyen, H. H., De Mot, R., Vanderleyden, J., et al. (2017). The plant growth-promoting effect of the nitrogen-fixing endophyte Pseudomonas stutzeri A15. Arch. Microbiol. 199, 513-517. doi: 10.1007/s00203-016-1332-3

Pilon-Smits, E. A., Quinn, C. F., Tapken, W., Malagoli, M., and Schiavon, M. (2009). Physiological functions of beneficial elements. Curr. Opin. Plant. Biol. 12, 267-274. doi: 10.1016/j.pbi.2009.04.009

Poston, J. M. (1977). Leucine 2, 3-aminomutase: a cobalamindependent enzyme present in bean seedlings. Science 195, 301-302. doi: $10.1126 /$ science.195.4275.301

Poston, J. M. (1978). Coenzyme B12-dependent enzymes in potatoes: leucine 2, 3-aminomutase and methylmalonyl-coa mutase. Phytochemistry 17, 401-402. doi: 10.1016/S0031-9422(00)89324-3

Puri, A., Padda, K. P., and Chanway, C. P. (2018). "Nitrogen-fixation by endophytic bacteria in agricultural crops: recent advances," in Nitrogen in Agriculture-Updates, eds A. Khan, S. Fahad (Rijeka: In Tech Publisher), 73-94. doi: 10.5772/intechopen. 71988

Raj, A. S. (1987). Cobalt nutrition of pigeonpea and peanut in relation to growth and yield. J. Plant Nutr. 10, 2137-2145. doi: 10.1080/01904168709363764

Rajakaruna, N., and Bohm, B. A. (2002). Serpentine and its vegetation: a preliminary study from Sri Lanka. J. Appl. Bot. Angewand. Bot. 76, 20-28.

Rana, K. L., Divjot, K., Tanvir, K., Rubee, D., Nath, Y. A., Neelam, Y., et al. (2020). Endophytic microbes: biodiversity, plant growth-promoting mechanisms and potential applications for agricultural sustainability. Antonie van Leeuwenhoek 113, 1075-1107. doi: 10.1007/s10482-020-01429-y

Rauser, W. (1981). Entry of sucrose into minor veins of bean seedlings exposed to phytotoxic burdens of Co, Ni or Zn. J. Plant. Nutr. 3, 319-328. doi: 10.1080/01904168109362840

Reddy, T. V. (1988). Mode of action of cobalt extending the vase life of cut roses. Sci. Hort. 36, 303-313. doi: 10.1016/0304-4238(88)90065-9

Reed, S. C., Cleveland, C. C., and Townsend, A. R. (2011). Functional ecology of free-living nitrogen fixation: a contemporary perspective. Annu. Rev. Ecol. Evol. Syst. 42, 489-512. doi: 10.1146/annurev-ecolsys-102710-145034

Reimann, C., Koller, F., Frengstad, B., Kashulina, G., Niskavaara, H., and Englmaier, P. (2001). Comparison of the element compositin in several plant species and their substrate from a $1555000 \mathrm{~km}^{2}$ area in northern Europe. Sci. Total. Environ. 278, 87-112. doi: 10.1016/S0048-9697(00)00890-1

Reisenauer, H. M. (1960). Cobalt in nitrogen fixation by a legume. Nature 186, 375-376. doi: 10.1038/186375a0

Ritika, B., and Dey, U. (2014). Biofertilizer, a way towards organic agriculture: a review. Afr. J. Microbiol. Res. 8, 2332-2343. doi: 10.5897/AJMR2013.6374
Roberts, S., and Gunn, G. (2014). "Cobalt," in Critical Metals Handbook, 1st Edn, ed G. Gunn (Nottingham: John Wiley and Sons), 122-147.

Robson, A. D., Dilworth, M. J., and Chatel, D. L. (1979). Cobalt and nitrogen fixation on Lupinus angusfifohus L. I. Growth nitrogen concentrations and cobalt distribution. New Phytol. 83, 53-62. doi: 10.1111/j.1469-8137.1979.tb00726.x

Rod, N. K., Gudadhe, N. N., Karmakar, N., Mehta, P. V., and Narwade, A. V. (2019). Cobalt chloride enhances crop duration, increases production, and productivity of chickpea. J. Plant. Nutr. 42, 40-57. doi: 10.1080/01904167.2018.1544258

Rodionov, D. A., Vitreschak, A. G., Mironov, A. A., and Gelfand, M. S. (2003). Comparative genomics of the vitamin B12 metabolism and regulation in prokaryotes. J. Bio. Chem. 278, 41148-41159. doi: 10.1074/jbc.M305837200

Rosenblueth, M., Ormeno-Orrillo, E., Lopez-Lopez, A., Rogel, M. A., ReyesHernandez, B. J., Martinez-Romero, J. C., et al. (2018). Nitrogen fixation in cereals. Front. Microbiol. 9:1794. doi: 10.3389/fmicb.2018.01794

Rothballer, M., Eckert, B., Schmid, M., Fekete, A., Schloter, M., Lehner, A., et al. (2008). Endophytic root colonization of gramineous plants by Herbaspirillum frisingense. FEMS Microbiol. Ecol. 66, 85-95. doi: 10.1111/j.1574-6941.2008.00582.x

Roughley, R. J., Gault, R. R., Gemell, L. G., Andrews, J. A., Brockwell, J., Dunn, B. W., et al. (1995). Autecology of Bradyrhizobium japonicum in soybean-rice rotations. Plant Soil 176, 7-14. doi: 10.1007/BF00017670

Sachdev, S., Ansari, S. A., Ansari, M. I., Fujita, M., and Hasanuzzaman, M. (2021). Abiotic stress and reactive oxygen species: generation, signaling and defense mechanisms. Antioxidants 10:277. doi: 10.3390/antiox10020277

Santoyo, G., Moreno-Hagelsieb, G., del Carmen Orozco-Mosqueda, M., and Glick, B. R. (2016). Plant growth-promoting bacterial endophytes. Microbiol. Res. 183, 92-99. doi: 10.1016/j.micres.2015.11.008

Saric, T., and Saciragic, B. (1969). Effect of oat seed treatment with microelements. Plant Soil 31, 185-187. doi: 10.1007/BF01373038

Sato, K., Kudo, K., and Muramatsu, K. (2004). Incorporation of a high level of vitamin B12 into a vegetable, kaiware daikon (Japanese radish sprout), by the absorption from its seeds. Biochim. Biophys. Acta. 1672, 135-137. doi: 10.1016/j.bbagen.2004.03.011

Serek, M., Woltering, E. J., E. C., Sisler, S. F., and Sriskandarajah, S. (2006). Controlling ethylene responses in flowers at the receptor level. Biotechnol. Adv. 24, 368-381. doi: 10.1016/j.biotechadv.2006.01.007

Setubal, J. C., Dos Santos, P., Goldman, B. S., Ertesvåg, H., Espin, G., Rubio, L. M., et al. (2009). Genome sequence of Azotobacter vinelandii, an obligate aerobe specialized to support diverse anaerobic metabolic processes. J. Bacteriol. 191, 4534-4545. doi: 10.1128/JB.00504-09

Shacklette, H. T. (1965). Element content of bryophytes. U.S. Geol. Survey Bull. 1198, 1-18.

Shahid, M., Niazi, N. K., Rinklebe, J., Bundschuh, J., Dumat, C., and Pinelli, E. (2020). Trace elements-induced phytohormesis: a critical review and mechanistic interpretation. Crit. Rev. Environ. Sci. Technol. 50, 1984-1932. doi: 10.1080/10643389.2019.1689061

Sillanpaa, M., and Jansson, H. (1992). Status of Cadmium, Lead, Cobalt and Selenium in Soils and Plants of Thirty Countries. Rome: FAO

Singh, D. K., Singh, A. K., Singh, M., Bordoloi, L. J., and Srivastava, O. P. (2012). Production potential and nutrient uptake efficiency of Pea (Pisum sativum L) as influenced by different fertility levels and micronutrients. J. Indian Soc. Soil Sci. 60, 1-6.

Singh, Z., Lakhvir, S., Arora, C. L., Dhillon, B. S., Singh, Z., and Singh, L. (1994). Effect of cobalt, cadmium, and nickel as inhibitors of ethylene biosynthesis on floral malformation, yield and fruit quality of mango. J. Plant. Nutr. 17, 1659-1670. doi: 10.1080/01904169409364838

Smith, I. C., and Carson, B. L. (1981). Trace Metals in the Environment. Ann Arbor, MI: Ann Arbor Science Publishers.

Soumare, A., Diedhiou, A. G., Thuita, M., Hafidi, M., Ouhdouch, Y., Gopalakrishnan, S., et al. (2020). Exploiting biological nitrogen fixation: a route towards a sustainable agriculture. Plants 9:1011. doi: 10.3390/plants9081011

Sree, K. S., Keresztes, A., Mueller-Roeber, B., Brandt, R., Eberius, M., Fischer, W., et al. (2015). Phytotoxicity of cobalt ions on the duckweed Lemna minor morphology, ion uptake, and starch accumulation. Chemosphere 131, 149-156. doi: 10.1016/j.chemosphere.2015.03.008 
Steenhoudt, O., and Vanderleyden, J. (2000). Azospirillum, a free-living nitrogen-fixing bacterium closely associated with grasses: genetic, biochemical and ecological aspects. FEMS Microbiol. Rev. 24, 487-506. doi: 10.1111/j.1574-6976.2000.tb00552.x

Tewari, R., Kumar, P., Sharma, P., and Bisht, S. (2002). Modulation of oxidative stress responsive enzymes by excess. Plant Sci. 162, 381-388. doi: 10.1016/S0168-9452(01)00578-7

Thomas, W. A. (1975). Cobalt accumulation and circulation by blackgum trees. For. Sci. 21, 222-226.

Tittle, F. L. (1987). Auxin-stimulated ethylene production in fern gametophytes and sporophytes. Physiol. Plant. 70, 499-502. doi: 10.1111/j.1399-3054.1987.tb02849.x

Tjong, E., Dimri, M., and Mohiuddin, S. S. (2020). Biochemistry, Tetrahydrofolate. Treasure Island, FL: StartPearls.

Tosh, S., Choudhuri, M. A., and Chatterjee, S. K. (1979). Retardation of lettuce (Lactuca sativa L.) leaf senescence by cobalt ions. Indian. J. Exp. Bio. 17, 1134-1136.

Trejo-Téllez, L. I., Gómez-Merino, F. C., Gómez-Pérez, V., and Castro-García, F. D. A. (2014). Cobalt in postharvest of gladiolus (Gladiolus grandiflorus Hort.). Rev. Mexicana Ciencias Agrícolas 28, 1575-1587.

Underwood, E. J., and Filmer, J. F. (1935). The determination of the biological potent element (cobalt) in limonite. Aust. Vet. J. 11, 84-92.

Van der Ent, A., Erskine, P., and Sumail, S. (2015). Ecology of nickel hyperaccumulator plants from ultramafic soils in Sabah (Malaysia). Chemoecology 25, 243-259. doi: 10.1007/s00049-015-0192-7

Van der Ent, A., Mak, R., de Jonge, M. D., and Harris, H. H. (2018). Simultaneous hyperaccumulation of nickel and cobalt in the tree Glochidion cf. sericeum (Phyllanthaceae): elemental distribution and chemical speciation. Sci. Rep. 8:9683. doi: 10.1038/s41598-018-26891-7

Van der Ent, A., and Reeves, R. D. (2015). Foliar metal accumulation in plants from copper-rich ultramafic outcrops: case studies from Malaysia and Brazil. Plant Soil 389, 401-418. doi: 10.1007/s11104-015-2385-9

Van Doorn, W. G., Zagory, D., and Reid, M. S. (1991). Role of ethylene and bacteria in vascular blockage of cut fronds from the fern Adiantum raddianum. Sci. Hort. 46, 161-169. doi: 10.1016/0304-4238(91)90102-5

Van Tran, L., and Teherani, D. K. (1989). Determination of trace elements in biological material by neutron activation analysis. J. Radio. Nucl. Chem. Let. 135, 443-448. doi: 10.1007/BF02164772

Velmourougane, K., Prasanna, R., Chawla, G., Nain, L., Kumar, A., and Saxena, A. K. (2019). Trichoderma-Azotobacter biofilm inoculation improves soil nutrient availability and plant growth in wheat and cotton. J. Basic Microbiol. 59, 632-644. doi: 10.1002/jobm.201900009

Vijayarengan, P., Jaleel, C. A., Zhao, C. X., Jayakumar, K., and Azooz, M. M. (2009). Biochemical variation in ground nut under Co application. Applications. Glob. J. Mol. Sci. 4, 19-22.

Wall, L. G. (2000). The actinorhizal symbiosis. J. Plant Growth Regul. 19, 167-182. doi: $10.1007 / \mathrm{s} 003440000027$

Wallace, A., Alexander, G. V., and Chaudhry, F. M. (1977). Phytotoxicity of cobalt, vanadium, silver and chromium. Commun. Soil Sci. Plant Anal. 8, 751-756. doi: 10.1080/00103627709366769

Wallace, A., E. M., Romney, D. C., Adriano, J. K. G., and Alexander, V. (1982). Sources of variation in mineral composition of selected plants inhabiting a floodplain at the Savannah River Site. Soil Sci. 134, 36-39. doi: 10.1097/00010694-198207000-00006

Wang, J. B., Tang, Y. L., Xu, J., Xu, G. C., Zou, Y., and Chen, H. (2015). Accumulation and distribution of cobalt in broad bean and its effects on the photosynthesis and antioxidant enzyme activities. Acta Bot. BorealiOccidentalia Sinica 35, 963-970.

Wang, W., Zhai, Y., Cao, L., Tan, H., and Zhang, R. (2016). Endophytic bacterial and fungal microbiota in sprouts, roots and stems of rice (Oryza sativa L.). Microbiol. Res. 188, 1-8. doi: 10.1016/j.micres.2016.04.009
Wani, S. A., Chand, S., Wani, M. A., Ramzan, M., and Hakeem, K. R. (2016). "Azotobacter chroococcum-a potential biofertilizer in agriculture: an overview," in Soil Science: Agricultural and Environmental Prospective, eds K. Hakeem, J. Akhtar, and M. Sabir (Cham: Springer), 333-348.

Watanabe, F., Abe, K., Takenaka, S., Tamura, Y., Maruyama, I., and Nakano, Y. (1997). Occurrence of cobalamin coenzymes in the photosynthetic green alga, Chlorella vulgaris. Biosci. Biotechnol. Biochem. 61, 896-897. doi: 10.1271/bbb.61.896

Watanabe, Y., Iizuka, T., and Shimada, N. (1994). Induction of cucumber leaf urease by cobalt. Soil Sci. Plant Nutr. 40, 545-548. doi: 10.1080/00380768.1994.10413333

Wei, X., Lyu, S., Yu, Y., Wang, Z., Liu, H., Pan, D., et al. (2017). Phylloremediation of air pollutants: exploiting the potential of plant leaves and leaf-associated microbes. Front. Plant Sci. 8:1318. doi: 10.3389/fpls.2017.01318

Wheeler, R. M., and Salisbury, F. B. (1981). Gravitropism in higher plant shoots: I. A Role for ethylene. Plant Physiol. 67, 686-690. doi: 10.1104/pp.67.4.686

Wilson, S. B., and Nicholas, D. J. D. (1967). A Cobalt reguirement for non-nodulated legumes and for wheat. Phytochemistry 6, 1057-1066. doi: 10.1016/S0031-9422(00)86062-8

Yamada, K. (2013). Cobalt: its role in health and disease. Met Ions Life Sci.13, 295-320. doi: 10.1007/978-94-007-7500-8_9

Yamaguchi, T., Tsukada, C., Takahama, K., Hirotomo, T., Tomioka, R., and Takenaka, C. (2019). Localization and speciation of cobalt and nickel in the leaves of the cobalt-hyperaccumulating tree Clethra barbinervis. Trees 33, 521-532. doi: 10.1007/s00468-018-1797-6

Yanni, Y., and El-Fattah, F. K. (1999). Towards integrated biofertilization management with free living and associative dinitrogen fixers for enhancing rice performance in the Nile delta. Symbiosis 27, 319-331.

Yao, S., Lyu, S., An, Y., Lu, J., Gjermansen, C., and Schramm, A. (2018). Microalgae-bacteria symbiosis in microalgal growth and biofuel production: a review. J. Appl. Microbiol. 126, 359-368. doi: 10.1111/jam. 14095

Yee, D., and Morel, F. M. (1996). In vivo substitution of zinc by cobalt in carbonic anhydrase of a marine diatom. Limnol. Oceanogr. 41, 573-577. doi: 10.4319/lo.1996.41.3.0573

Yoo, S., Cho, S., Sugimoto, H., Li, J., Kusumi, K., Koh, H., et al. (2009). Rice virescent 3 and stripe 1 encoding the large and small subunits of ribonucleotide reductase are required for chloroplast biogenesis during early leaf development. Plant Physiol. 150, 388-401. doi: 10.1104/pp.109.136648

Zhang, Y., Rodionov, D. A., Gelfand, M. S., and Gladyshev, V. N. (2009). Comparative genomic analyses of nickel, cobalt and vitamin B12 utilization. BMC Genomics 10:78. doi: 10.1186/1471-216 4-10-78

Conflict of Interest: The authors declare that the research was conducted in the absence of any commercial or financial relationships that could be construed as a potential conflict of interest.

Publisher's Note: All claims expressed in this article are solely those of the authors and do not necessarily represent those of their affiliated organizations, or those of the publisher, the editors and the reviewers. Any product that may be evaluated in this article, or claim that may be made by its manufacturer, is not guaranteed or endorsed by the publisher.

Copyright $(52021 \mathrm{Hu}$, Wei, Ling and Chen. This is an open-access article distributed under the terms of the Creative Commons Attribution License (CC BY). The use, distribution or reproduction in other forums is permitted, provided the original author(s) and the copyright owner(s) are credited and that the original publication in this journal is cited, in accordance with accepted academic practice. No use, distribution or reproduction is permitted which does not comply with these terms. 